\title{
ORIGEM E EVOLUÇÃO DA SERRA DO MAR
}

\author{
FERNANDO FLÁVIO MARQUES DE ALMEIDA* \& CELSO DAL RÉ CARNEIRO**
}

\begin{abstract}
ORIGIN AND EVOLUTION OF THE SERRA DO M AR The origin of the subparallel mountain systems which compose the coastal Serra do Mar and the inland Serra da Mantiqueira is related to the Upper Cretaceous. These features - distributed along a quite singular continental atlantic border - nave a complex evolution arising controversial questions. The answers to these problems are mainly dependentto the dating of the Japi erosional surface and other younger ones, a study still faced by the small amount of detailed-scale surveys. The scarp domains covered by dense vegetation often impose difficult trail access. Nevertheless, the present knowledge stage allows us to admit that during Tertiary the evolution of the local relief hás affected into a considerable extent the synchronic oceanic phase sediments of the Santos Basin. There is a lot of evidence and proofs that the Serra do Mar hás been developed from a very different geographical position as compared to the existing one. The hypothesis supported by the present authors is a long-term scarp retreat from southeast to northwest due to erosional processes approximately starting at the Santos fault line in the present continental platform.
\end{abstract}

Keywords:

RESUMO A origem dos sistemas montanhosos subparalelos que compõem as serras do Mar e da Mantiqueira remonta provavelmente ao Paleoceno. A evolução de tais feiçôes ímpares da borda atlântica do continente tem. despertado questões controvertidas, cuja resolução é sobretudo balizada pela idade das superfícies de erosão do Japi e outras mais novas, cujos indícios são encontrados no Planalto Atlântico. O estudo é dificultado pelo pequeno volume de levantamentos em escala de detalhe ao longo desses domínios escarpados, muitas vezes de difícil acesso e recobertos por densa vegetação. Entretanto, os conhecimentos atuais permitem admitir que, durante o Terciário, a evolução do relevo regional tenha afetado grande parte dos registros sincrônicos da Bacia de Santos, restando muitas evidências e provas de que as escarpas da Serra do Mar desenvolveram-se bem mais a leste que a posição geográfica atual. A mudança de posição, hipótese defendida neste trabalho, é principalmente devida ao recuo erosivo diferencial condicionado pelas estruturas e unidades litológicas pré-cambrianas.

Palavras-chaves:

INTRODUÇÃO O sistema de montanhas representado pelas serras do Mar e da Mantiqueira constitui a mais destacada feição orográfica da borda atlântica do continente sul-americano (Fig. 1). Aspectos geológicos relacionados à origem e evolução das serras ainda são pouco conhecidos, e se constituem em problemas complexos sobre os quais as opiniões de geólogos e geomorfólogos divergem.

A Serra do Mar é um conjunto de escarpas festonadas com cerca de $1.000 \mathrm{~km}$ de extensão, em que termina o Planalto Atlântico no trecho voltado para a Bacia de Santos. Ela se estende do Rio de Janeiro ao norte de Santa Catarina, onde deixa de existir como unidade orográfica de borda escarpada de planalto, desfeita que se acha em cordões de serras paralelas e montanhas isoladas drenadas diretamente para o mar, sobretudo pela bacia do rio Itajá. No Paraná configura uma cadeia de montanhas com cimos elevados até a $1.800 \mathrm{~m}$ de altitude. Em São Paulo, impõe-se como típica borda de planalto, frequentemente nivelada pelo topo em altitudes de 800 a 1.200 $\mathrm{m}$. Na região centro-oriental do Rio de Janeiro apresenta-se como uma montanha constituída por bloco de falhas inclinado para nor-noroeste em direção ao rio Paraíba do Sul (Fig. 2), com vertentes abruptas voltadas para a Baixada Fluminense, a sul.

A origem da Serra do Mar tem suscitado dúvidas. Sobretudo geógrafos, mas também muitos geólogos, atribuem-na a processos tectônicos de movimentação vertical realizados no Cenozóico (Almeida 1976, Asmus \& Ferrari 1978), no sítio onde ela se localiza. Seria portanto, em seu conjunto, um grande fronte dissecado de falhas em que termina o Planalto Atlântico.

Salienta-se o interesse prático do estudo da origem e evolução desse extenso e elevado desnível topográfico, quando se considera que desde há muito a engenharia e a técnica nacionais são desafiadas pela sua transposição. $\mathrm{O}$ presente texto assinala fatos importantes para a ocupação humana que decorrem da peculiar situação geológica e geográfica da serra. Diante dos múltiplos e diferentes efeitos da ação humana na serra, torna-se conveniente apontar aspectos relacionados à apropriação desse espaço pelo Homem, como subsídio a novas pesquisas sobre a dinâmica das encostas, cujo entendimento é fundamental para a preservação de tais domínios.

Os modernos conhecimentos sobre a estratigrafia da Bacia de Santos (Pereira et al 1986, Pereira \& Feijó 1994), obtidos pela Petrobrás, indicam que um relevo destacado existiu no Cretáceo Superior não longe de sua borda, relevo cuja erosão forneceu grande quantidade de detritos grossos que se acumularam na plataforma externa e na borda proximal da bacia. Seria uma proto-Serra do Mar.

Neste trabalho os autores procuram analisar a origem e evolução da Serra do Mar a partir de falha situada na atual plataforma continental, de onde recuou sobretudo por erosão até a posição geográfica que atualmente ocupa.

ESTRUTURA GEOLÓGICA Geologia do Escudo Attântico A direção geral da Serra do Mar acompanha a orientação ENE das estruturas do Escudo Atlântico (Fig. 3). Em mapas de escala maior, porém, a crista das escarpas é extremamente festonada (Ponçano et al. 1981), pois acompanha estruturas menores e falhas, além de obedecer à decisiva, embora heterogénea, influência de corpos rochosos resistentes à denudação. A complexa história registrada entre o Pré-cambriano e o Eopaleozóico, que deu origem a diversas associações migmatíticas e metamórficas, bem como a inúmeros complexos ígneos, explica a ampla variedade de tipos litológicos do embasamento exposto.

Os estágios evolutivos do embasamento costeiro são ainda mal conhecidos. As idades mais antigas distribuem-se do Arqueano ao Proterozóico Inferior. Tais núcleos são englobados por rochas e estruturas representativas de três grandes

* Professor Catedrático Aposentado (Mineralogia, Petrografia e Geologia) da Escola Politécnica, USP. Al. Franca 432, Ap. 9, CEP 01422-000, São Paulo SP

** Departamento de Geociências Aplicadas ao Ensino, Instituto de Geociências UNICAMP. Caixa Postal 6152, CEP 13083-970, Fax (019) 239 1562, Campinas SP.E-mail: cedrec@ige.unicamp.br 
colagens proterozóicas vinculadas aos supercontinentes Atlântica (Paleoproterozóico), Rodínia (MesoproterozóicoNeoproterozóico) e Gondwana Ocidental (final do Neoproterozóico). As sucessivas colagens e interações de placas formaram faixas móveis acrescionárias, colisionais ou transpressionais, retomadas sucessivas vezes (Almeida et al. 1997). Após cada uma delas, sucederam-se processos de tafrogenia e dispersão de supercontinentes, acompanhados de magmatismo anorogênico e sedimentação intracratônica. As faixas móveis circundam núcleos menores, que foram reestruturados e afetados pela orogenia transamazônica. Rochas arqueanas - que abrangem desde gnaisses, migmatitos e granulitos, até rochas ultramáficas e metaultramáficas - estão preservadas no bloco neoproterozóico Luís Alves (SC-PR), no extremo sul da Serra do Mar, estendendo-se até aproximadamente a Serra dos Itatins, no litoral sul de SP.

As faixas Paraíba do Sul e Ribeira - compostas por associações complexas de gnaisses e xistos, com relíquias de rochas metasupracrustais - incluem na sua infra-estrutura os complexos Juiz de Fora, Cabo Frio e Embu, formados por rochas transamazônicas. Na parte marginal sul da faixa Apiaí (Fig. 4), o bloco situado entre as faixas brasilianas Ribeira e Dom Feliciano é formado por migmatitos, gnaisses, granulitos e xistos subordinados, afetados por retrabalhamento mesozonal extensivo. Nela ocorre longo colar de granitos alcalinos

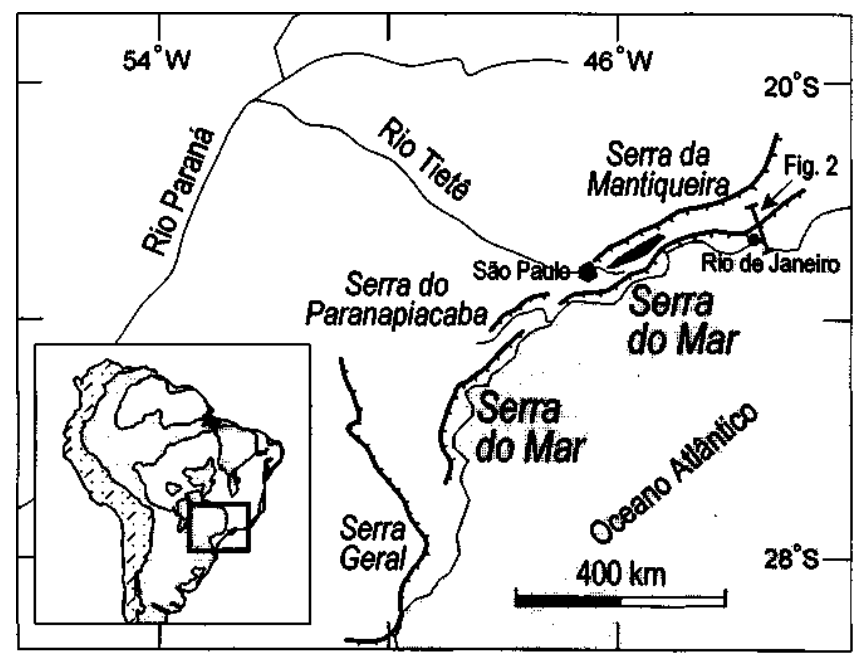

Figura l- Posição geográfica das principais serras da região sudeste do Brasil

Figure 1- Geographic position of the main coastal mountain belts in the southeastern region of Brazil anorogênicos, neoproterozóicos a cambrianos que, por sua resistência à erosão, sustentam a borda da Serra do Mar na região do primeiro planalto paranaense.

$\mathrm{Na}$ região focalizada afloram abundantes granitos neoproterozóicos, sobretudo formados durante o processo de consolidação do embasamento da Plataforma Sul-Americana (final do Proterozóico a Cambriano). Esses corpos, associados às derradeiras colisões de placas e soerguimento de cadeias montanhosas, dão suporte a grandes setores da Serra do Mar. No final do Proterozóico, com o arrefecimento do calor e mudança no regime de esforços, a compressão originou inúmeras falhas transcorrentes que recortam o sudeste brasileiro. Desse estágio final, no Cambro-Ordoviciano, resultou denso arranjo de zonas de cisalhamento dextrais anastomosadas, orientadas segundo ENE a E-W (Hasui \& Sadowski 1976).

Durante a separação mesozóica, que subdividiu o supercontinente Gondwana e culminou na abertura do Oceano Atlântico, inúmeras descontinuidades mais antigas foram reativadas em pulsos descontínuos que perduraram desde o Cretáceo até o Terciário. As rochas das falhas reativadas e mesmo das zonas de cisalhamento antigas, devido à baixa resistência à erosão diferencial, governam o traçado da rede de drenagem. Nos planaltos, há que se lembrar ainda a rede densa e onipresente de sistemas de juntas, que obedecem a distintas direções preferenciais. Em adição, Riccomini et al. (1989) descrevem evidências de falhamento tectônico em camadas sedimentares de idade pleistocênica ou até mesmo mais novas.

O traçado da Serra do Mar tem notável descontinuidade, entre as cercanias do Maciço de Itatins até a zona limítrofe de São Paulo e Paraná (ver Carneiro et al. 1981), onde a erosão avançou para o interior do continente, alcançando rochas da bacia Açungui, constituída de filitos, metarenitos, xistos, rochas carbonáticas a dolomíticas e, localmente, rochas metavulcânicas e formação ferrífera bandada. Dispostas em domínios adjacentes, cuja distribuição primária é de difícil recomposição, tais rochas foram afetadas por cavalgamentos, dobramentos e transcorrências (Fiori 1994). No Paraná as escarpas da Serra do Mar não atingiram tais formações, retardadas nos processos erosivos por um conjunto de stocks e batólitos graníticos fini-brasilianos. Não obstante, a erosão remontante da bacia hidrográfica do rio Ribeira propiciou forte entalhamento que se abre desde a zona costeira, junto aos tipos litológicos da Zona de Cisalhamento (ZC) LancinhaCubatão (Salamuni 1995), até atingir a região a norte de Curitiba, aproveitanto sua menor resistência à erosão diferencial.

Ainda quanto ao controle litológico do relevo, desempenham papel expressivo rochas resistentes como os maciços

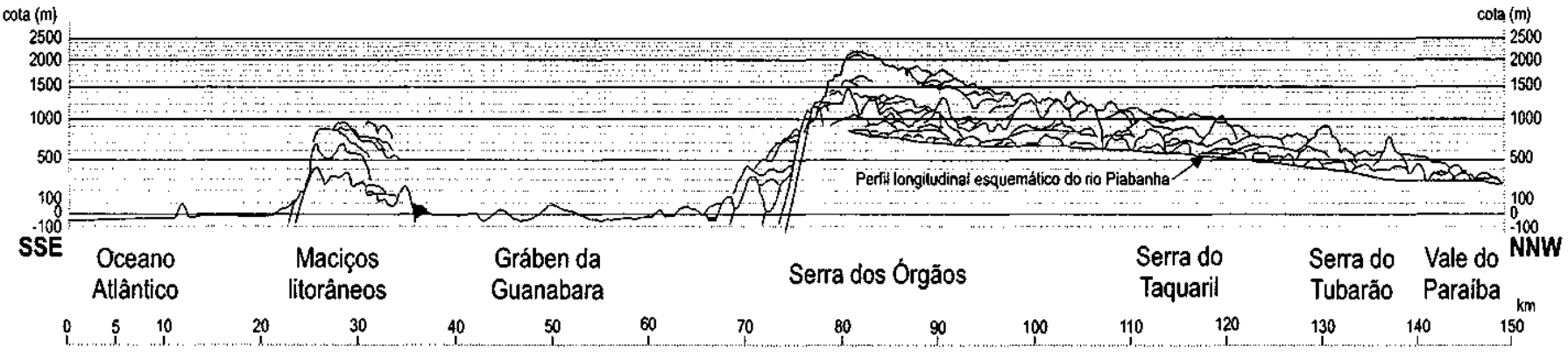

Figura 2 - Perfil esquemático transversal às estruturas geológicas da região entre o Oceano Atlântico e o Vale do Paraíba, no estado do Rio de Janeiro. A região correspondente ao Gráben da Guanabara acha-se indicada. Escala vertical logarítmica (modificado de Ruellan 1944)

Figure 2 - Section perpendicular to the geologic structures of the region between the Atlantic Ocean and the Paraíba do Sul Ri ver Valley, Rio de Janeiro state. The position of the Guanabara Gráben is indicated. Logarithmic vertical scale (modified from Ruellan 1944) 


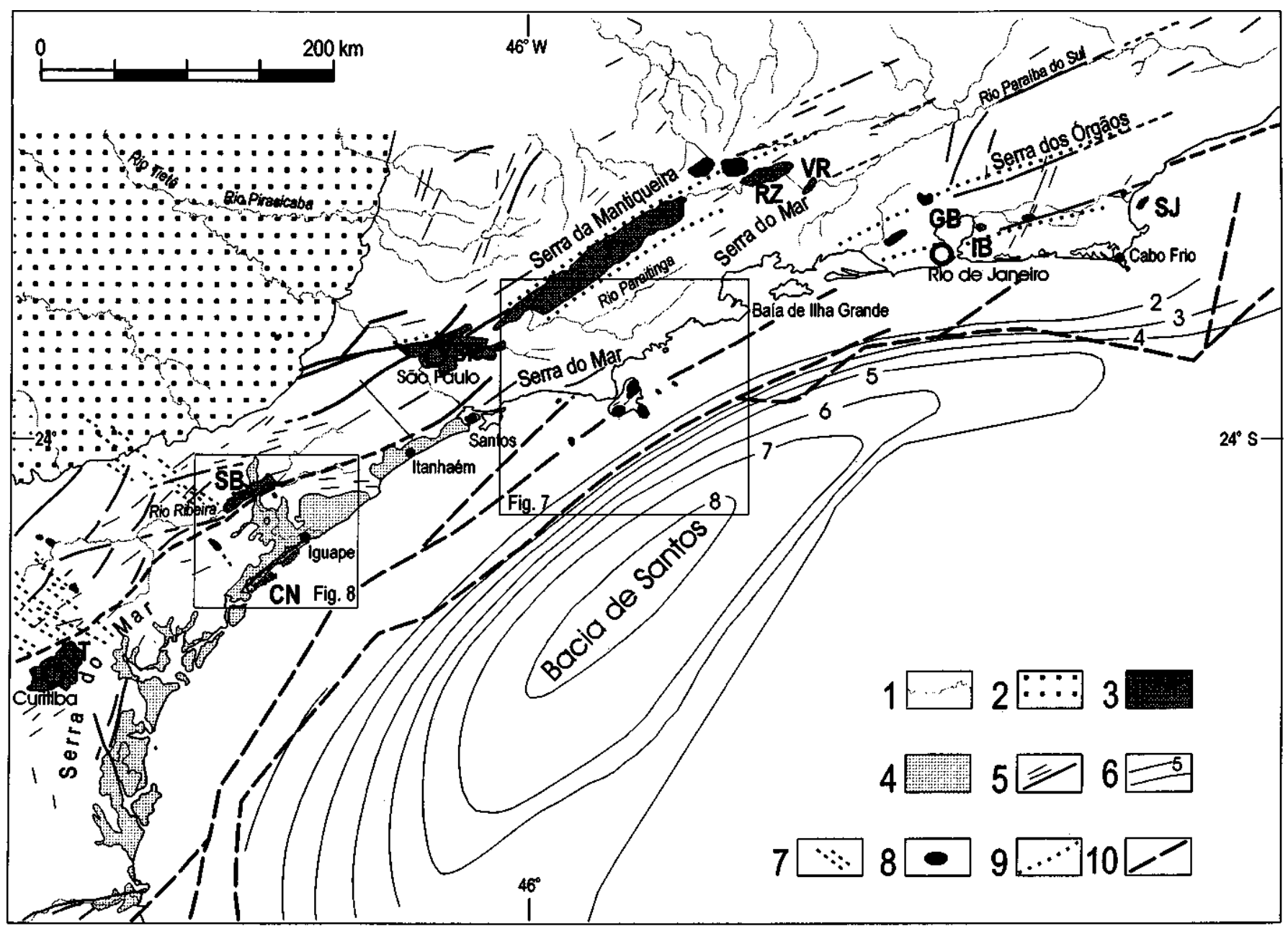

Figura 3 - Distribuição das principais feições geológicas da região sudeste do País adjacentes à Bacia de Santos, entre Santa Catarina e o Rio de Janeiro. Convenções: 1. Rede de drenagem no embasamento, 2. Bacia do Paraná, 3. Bacias tafrogênicas continentais: (CT) Curitiba, (SB) Sete Barras, (CN) Cananéia, (SP) São Paulo, (TT) Taubaté, (RZ) Resende, (VR) Volta Redonda, (GB) Guanabara, (IB) São José de Itaboraí, (SJ) Barra de São João, 4. Cobertura cenozóica, 5. Alinhamentos estruturais e falhas, 6. Linhas de contorno estrutural do embasamento, 7. Diques, 8. Corpos alcalinos, 9. Limites topográficos de rifles, 10. Falhas na área submersa

Figure 3 - Distribution of the principal geologic features of the southeastern coast adjacent to the Santos Basin, between Santa Catarina and Rio de Janeiro states. Legend: 1. Basement drainage, 2. Paraná basin, 3. Continental taphrogenic basins: (CT) Curitiba, (SB) Sete Barras, (CN) Cananéia, (SP) São Paulo, (TT) Taubaté, (RZ) Resende, (VR) Volta Redonda, (GB) Guanabara, (IB) São José de Itaboraí, (SJ) Barra de São João, 4. Cenozoic cover, 5. Structural lineaments and faults, 6. Structural contour lines of basement, 7. Dikes, 8 . Alkaline bodies, 9 . Topographic limits of rifts, 10. Faults in the submerged área

alcalinos mesozóicos que ocorrem em Itatiaia e Passa-Quatro, sustentando montanhas destacadas em relação às mais altas elevações da Serra da Mantiqueira. Da mesma forma, três dos quatro corpos reconhecidos na Ilha de São Sebastião são principalmente formados por nefelina sienitos. O corpo das Canas é composto de rochas básico-alcalinas, como ijolitos a gabros nefelínicos (Hennies \& Hasui 1977). Adiante é discutido que a presença desse grande promontório é em parte explicada pela existência, em direção ao mar, das proeminentes elevações sustentadas por rochas alcalinas.

Rochas resistentes sustentam planaltos e escarpas, enquanto falhas, zonas de cisalhamento, fraturas e grandes domínios de rochas supracrustais condicionam lineamentos maiores e segmentos locais da rede de drenagem. Evidências de reativação têm sido descritas para muitas das principais zonas de cisalhamento e falhas regionais do sudeste brasileiro. Tal evolução, originada no Mesozóico e talvez interrompida com a cessação dos pulsos magmáticos que originaram os diques de intrusivas básicas instalados em muitas dessas ZCs, acentuou-se no Paleógeno e prosseguiu, atenuada, durante o
Neógeno e Quaternário, até os dias atuais (Riccomini et al. 1989, Suguio 1996). Esse contexto litológico constitui embasamento para deposição de vários pacotes de rochas sedimentares, entre o Terciário e o Quaternário, nas bacias tafrogênicas de Curitiba, São Paulo, Taubaté, Resende e Volta Redonda. Os grábens de Sete Barras e Cananéia constituem zonas deprimidas, em cotas que não excedem $50 \mathrm{~m}$, que foram escavadas durante o recuo erosivo da serra. Seu assoalho encontra-se respectivamente a 100-200 e até cerca de $500 \mathrm{~m}$ sob o nível do mar.

AS SUPERFÍCIES DE EROSÃO DO PLANALTO ATLÂNTICO Uma referência deve ser feita às principais superfícies de erosão pós-paleozóicas da região sudeste do Planalto Atlântico do País. Como se verá, elas fornecem indícios sobre a origem e evolução da Serra do Mar a partir de um sítio que não é o que ela hoje ocupa. A mais antiga delas foi identificada por Martonne (1943) como "Superficie das Cristas Médias" e por Almeida (1958) denominada Japi. Sua 


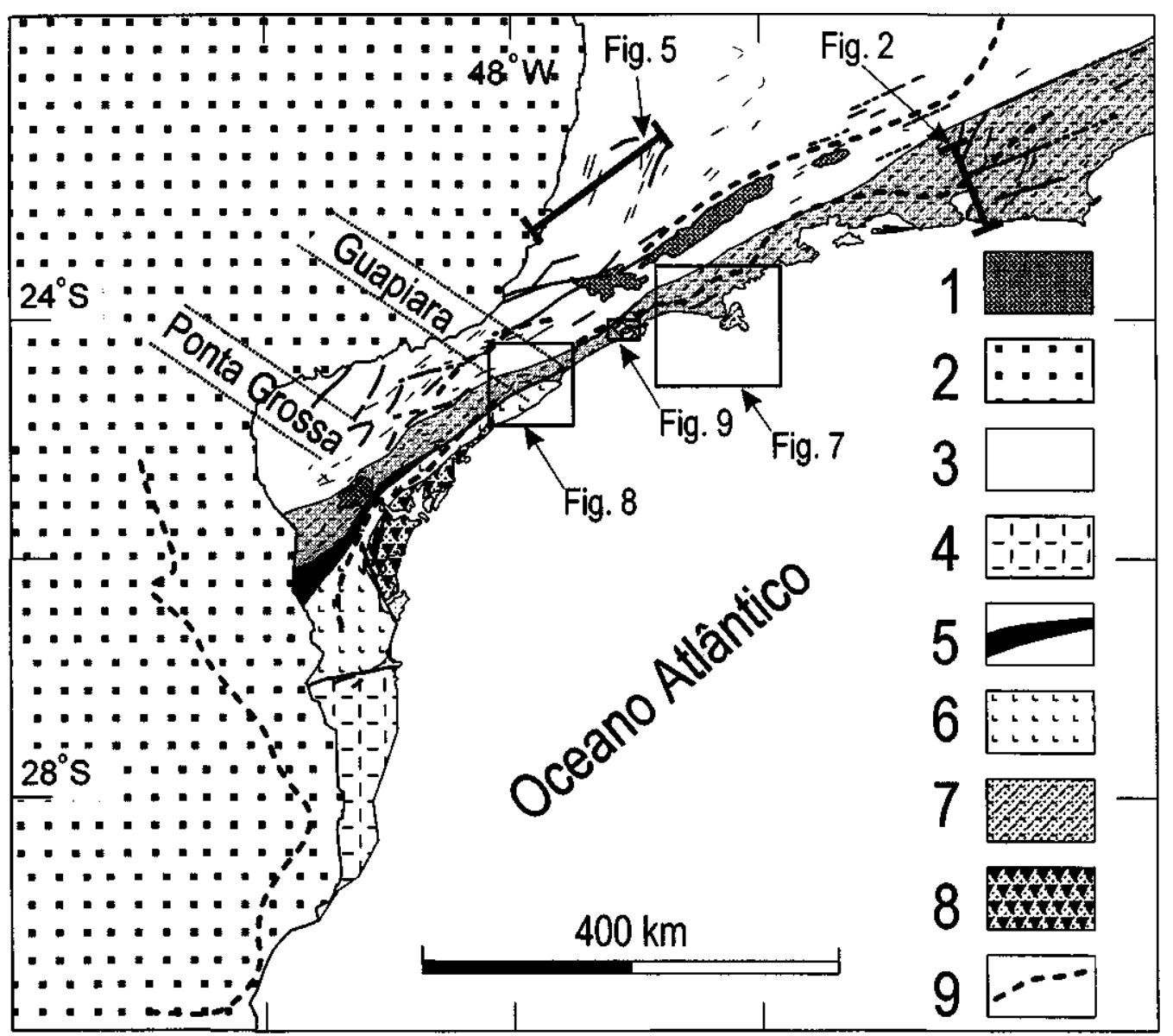

Figura 4 - Principais domínios tectônicos continentais adjacentes à Bacia de Santos. Convenções: 1. Bacias tafrogênicas terciárias, 2. Bacia do Paraná, 3. Domínios retrabalhados e metavulcano-sedimentares das Faixas Paraiba do Sul, Apiai e Ribeira, 4. Domínios metavulcano-sedimentares da Faixa Tijucas, 5. Colar de granitos cálcio-alcalinos, 6. Rochas granito-gnáissico-migmatíticas retrabalhadas no Brasiliano, 7. Complexo Costeiro, 8. Rochas arqueanas gnáissico-granuliticas retrabalhadas no

Transamazônico, 9. Serras

Figure 4 - Main continental tectonic domains adjoining the Santos Basin. Legend: 1. Tertiary taphrogenic basins, 2. Paraná Basin, 3. Reworked and metavolcano-sedimentary domains of the Paraíba do Sul, Apiaí and Ribeira belts, 4. Metavolcano-sedimentary domains of the Tijucas belts, 5. Calc-alkaline granites, 6. Suite of granite, gneissic and migmatic rocks reworked during the Brasiliano cycle, 7. Costeiro Complex, 8. Archean gneissic-granulitic rocks reworked during the Transamazonian cycle, 9 . Mountain belts

equivalente no Paraná é a superfície do Purunã (Ab'Saber e Bigarella 1961). Seus indícios apresentam-se em grandes extensões do Brasil Sudeste, seja nivelando cumiadas de serras ou, localmente, restos de planaltos elevados. Onde não deformada, sua altitude na região oriental do Planalto Atlântico é de $1.200-1.300 \mathrm{~m}$. Tal superficie nivela as mais variadas estruturas, salvo umas poucas mais resistentes, como maciços graníticos neoproterozóicos/cambrianos na Serra do Mar no Paraná e as mais novas intrusões alcalinas cretáceas da Serra da Mantiqueira.

A idade da superficie de aplainamento Japi é razoavelmente bem conhecida. Ela nivela as intrusões alcalinas senonianas do oeste de Minas e sudeste de Goiás, datadas (K/Ar) por Hasui e Cordani (1968): Araxá (87-95 Ma); São Gotardo (80 Ma); Salitre (78-83 Ma); Catalão (83 Ma); Tapira (70 Ma), assim como o maciço de Poços de Caldas (63-80 Ma, Amaral et al. 1967). Na Serra da Mantiqueira, os maciços de Itatiaia (73 Ma por K/Ar) e Passa Quatro (66,7 Ma por K/Ar e 70,3 por $\mathrm{Rb} / \mathrm{Sr}$, (Lauar 1988 e Kinoshita, inédito, apud Riccomini 1989) não chegaram a ser arrasados e elevam-se até cerca de 800 metros acima da Superfície Japi.
A pequena bacia calcária de São José de Itaboraí a $10 \mathrm{~km}$ a sul de Itaboraí (RJ) contém uma fauna de vertebrados, entre eles mamíferos datados por Couto $(1953,1958)$ provavelmente do Neopaleoceno. Localiza-se no interior do gráben da Guanabara, entre a Serra dos Órgãos e os Maciços Litorâneos, portanto num semigráben formado com a destruição da superfície de aplainamento Japi. A pequena dimensão dessa bacia, pois que não tem mais de $1.500 \mathrm{~m}$ de diâmetro, é desproporcional à grande importância que ela apresenta por atestar um magno evento tectônico que deformou a superfície entre o final do Cretáceo e início do Terciário, prosseguindo menos intensamente no Eoceno/Oligoceno e provavelmente até o Eoa Mesomioceno. Seja por falta de tempo e, ou, intensidade, a erosão não foi suficiente para arrasar as grandes intrusões alcalinas de Itatiaia e Passa Quatro durante o Cretáceo, assim como as de Mendanha, Tinguá e Rio Bonito, no gráben da Guanabara.

A superfície de aplainamento Japi foi deformada por flexuras e grandes falhamentos. A figura 5, obtida de Almeida (1964), indica a projeção de perfis paralelos, da região de Serra Negra (SP) para os campos do Ribeirão Fundo (MG), em direção $70^{\circ} \mathrm{NE}$. A superficie ergue-se gradualmente por flexão 
até $1.650 \mathrm{~m}$. Daí ao topo da Serra da Mantiqueira a superfície eleva-se, talvez por falhas, a $2.000-2.100 \mathrm{~m}$ de altitude no planalto de Campos do Jordão.

Durante a deformação da superfície Japi o Planalto Atlântico sofreu importantes desnivelamentos por falhas, desenvolvendo semigrábens com inclinação para $\mathrm{NNW}$, orientados segundo direções ENE dos falhamentos pré-cambrianos então reativados. Esse sistema de bacias tafrogênicas é subparalelo à Serra do Mar assim como à charneira da Bacia de Santos e a falhamentos identificados na plataforma continental rasa (Fig. 3). As principais dessas bacias são as de São Paulo, Taubaté, Resende, Volta Redonda e Guanabara. Elas são preenchidas por sedimentos continentais de idade eocênica a miocênica, e desde o Paleoceno na Bacia de Itaboraí. Das quatro primeiras, a de Taubaté tem seu assoalho rebaixado a mais de $2.000 \mathrm{~m}$ em relação à superfície Japi no topo da Mantiqueira, no planalto de Campos do Jordão.

Essas bacias, particularmente as drenadas pelo rio Paraíba do Sul, têm sido motivo de muitos estudos tectônicos e sedimentares, de síntese e de detalhe, como os de Almeida (1976), Hasui et al. (1978), Melo et al. (1985), Riccomini (1989), Ferrari (1990) e Moriak, Barros (1990). A Bacia de Curitiba, no Estado do Paraná, pertence ao mesmo sistema mas foi pouco investigada. Também os denominados grábens de Sete Barras (Melo et al. 1989), no vale do rio Ribeira, e de Cananéia, na planície costeira Cananéia-Iguape (Souza et al. 1996), parecem a ele pertencer, por sua orientação e idade cenozóica.

Além da sedimentação calcária paleocênica da bacia de Itaboraí, o gráben da Guanabara, a única das bacias tafrogênicas invadida pelo mar no Quaternário, contém espessura de cerca de $200 \mathrm{~m}$ de depósitos continentais que Méis e Amador (1977) denominaram formações Pré-Macacu e Macacu. Lima et al. (1996) reuniram-nas em uma única Formação Macacu, e com base em análise palinológica determinaram sua idade como eocênica/oligocênica, o que mais vem aproximar esse semigráben dos drenados pelo rio Paraíba do Sul.

Além de diques de diabásio correlacionados ao magmatismo da Formação Serra Geral (White 1906), que também existem em grande número nos semigrábens drenados por aquele rio, o gráben da Guanabara possui numerosos diques, plugs e stocks de rochas alcalinas, cujas idades variam do Senoniano ao Eoceno. A se julgar pelas datações disponíveis (K/Ar, cf. Amaral et al. 1967) as grandes intrusões de rochas alcalinas no interior do gráben (Marapicu, $72 \mathrm{Ma}$; Tinguá, 66 Ma e Rio Bonito, $69 \mathrm{Ma}$ ) são anteriores ao afundamento do mesmo, à semelhança da intrusão de Morro Redondo (65 Ma, Ribeiro Filho e Cordani 1966) junto à Bacia de Resende no gráben do Paraíba. Também derrames eocênicos de ankaramito existem na bacia de Volta Redonda (Riccomini et al. 1983) e Itaboraí (Klein e Valença 1984). A Serra dos Órgãos, nome local da Serra do Mar à borda norte do semi- gráben da Guanabara, é um bloco de falha, em batólito granítico, basculado para norte (Ruellan 1944). Seu cimo atinge $2.218 \mathrm{~m}$ na Pedra do Sino, destacando-se acima de uma superficie sub-horizontal que nivela cumeadas e topos arredondados a $2.000 \mathrm{~m}$ de altitude. Martonne (1943) consideroua correlacionável à superfície dos Campos (Japi). A vertente inclinada para o vale do rio Paraíba tem cimos subnivelados por essa superficie. O bloco sul do semigráben é representado pelos Maciços Litorâneos, que incluem a ilha Grande na enseada de Angra dos Reis e os morros próximos à costa, como os maciços da Carioca, Niterói e outros.

$\mathrm{Na}$ Bacia de Santos o importante evento tectônico que deformou a superficie Japi e deu origem aos semigrábens está bem assinalado pela discordância (Fig. 6) que separa as sequências deposicionais indicadas por Pereira e Feijó (1994) como K-120 (maastrichtiana) e T-10 (paleocena). No entanto, Macedo (1991) correlaciona essa discordância à superfície Japi.

Superficies de erosão neogênicas mais ou menos evoluídas desenvolveram-se em diferentes níveis nas bacias dos principais rios do Planalto Atlântico. São certamente mais novas que a superfície de aplainamento Japi, já então deformada, mas sua datação ainda depende de estudos. Na bacia hidrográfica do rio Tietê, estende-se em grande área a superficie de erosão do Alto Tietê (Almeida 1958). Apresenta-se como um subnivelamento de cimos do relevo em rochas metamórficas menos resistentes à erosão. Tem altitude de $850 \mathrm{~m}$ onde nivela o topo da Serra do Mar (localmente denominada Serra do Cubatão), a noroeste de Santos, caindo a $800 \mathrm{~m}$ junto à Serra da Cantareira a norte de São Paulo. No Paraná a superfície do Alto Iguaçu (Almeida 1955) é uma das mais importantes do primeiro planalto. Nivela as estruturas pré-cambrianas a aproximadamente $1.100 \mathrm{~m}$.

ORIGEM DA SERRA DO MAR Uma conclusão importante a se tirar do nivelamento dos cimos da Serra do Mar pelas superficies de aplainamento do Japi e Alto Tietê é que quando elas se elaboraram o Planalto Atlântico se estendia bem mais para leste da área hoje ocupada pela plataforma continental interna. Uma superfície de aplainamento com a extensão da do Japi, identificada em vasta região do sudeste do País, necessariamente prosseguia, em sua origem, para a área hoje ocupada por parte da plataforma continental.

Após uma grande transgressão marinha havida na Bacia de Santos, com máximo no Neocenomaniano/Eoturoniano, realizou-se erosão subaérea e submarina da sequência neoturoniana dando origem a uma discordância com o Eoconiaciano, há cerca de 88-89,5 Ma (Pereira 1992). A discordância reflete um importante evento tectônico, que resultou em soerguimento pulsativo da área a oeste da bacia, estendendo-se até $\mathrm{o}$ interior do continente (Pereira et al. 1996). Esse soerguimento prosseguiu durante o Senoniano, constituindo área-

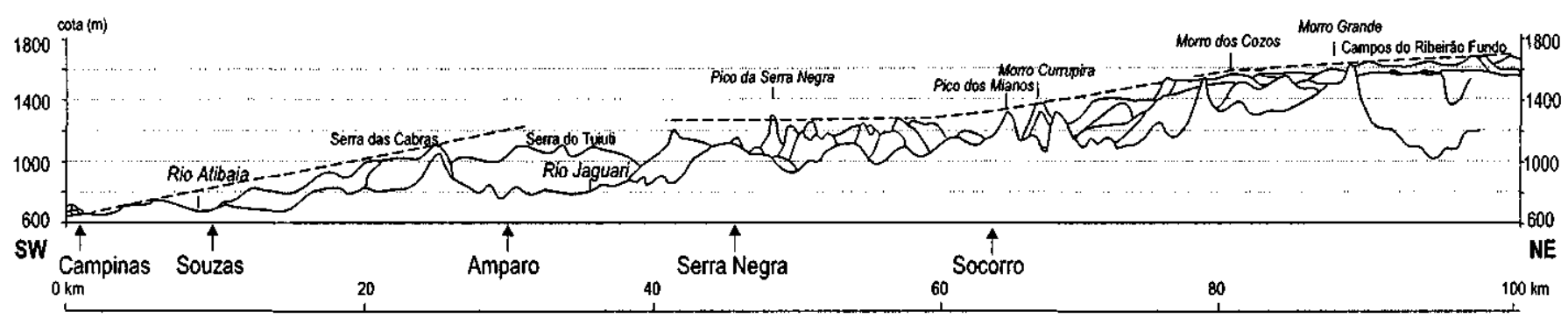

Figura 5 - Perfis paralelos projetados segundo a direção $70^{\circ} \mathrm{NE}$ entre a região de Serra Negra (SP) e os campos do Ribeirão Fundo (MG), ilustrando o soerguimento da Superficie Japi

Figure 5 - Parallel $70^{\circ} \mathrm{NE}$-oriented profiles along the Serra Negra region (SP) and the Ribeirão Fundo fields (MG), illustrating the uplift of the Japi Erosional Surface 


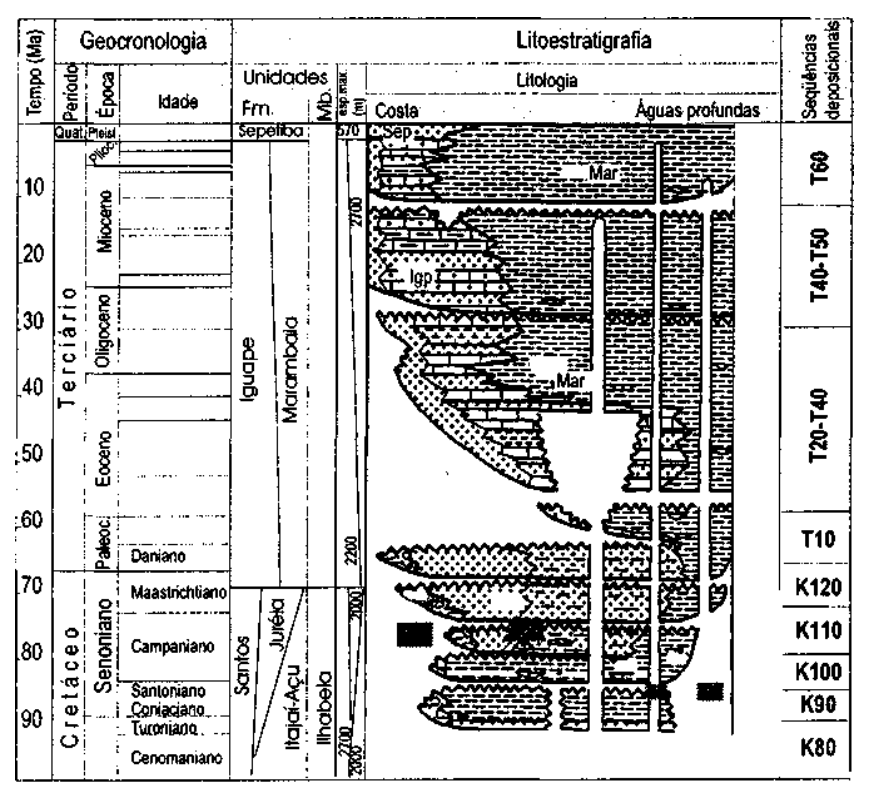

Figura 6 - Parte simplificada da coluna estratigráfica pós-albiana da Bacia de Santos (modificada de Pereira e Feijó 1994) indicando a influência, na coluna sedimentar, dos episódios erosivos da área continental adjacente Figure 6 - Influence of the continental erosional episodes in the sedimentary column as indicated by the simplified post-Albian stratigraphic column of the Santos Basin (modified from Pereira and Feijó 1994)

fonte das formações Santos, Juréia e Itajaí-Açu. A primeira compreende conglomerados, arenitos líticos vermelhos com intercalações de folhelhos cinzentos e arguas vermelhas (Ojeda e Césero 1973), indicativos de sedimentação em ambiente continental a transicional na forma de leques aluviais, rios entrelaçados e deltas (Pereira et al. 1986). A Formação Juréia constitui-se de arenitos finos, siltitos, folhelhos e calcilutitos que indicam deposição em plataforma marinha. A Formação Itajaí-Açu, onde predominam folhelhos cinza-escuros, representa a porção depositada em talude e bacia, sendo testemunhada em águas profundas. A grande espessura e extensão que as formações Santos e Juréia adquirem na borda proximal da bacia (Fig. 6) bem indicam a importância do relevo surgido com o soerguimento.

$\mathrm{O}$ soerguimento, progressivo e pulsativo, da área plataformal e continental vizinha à bacia foi atribuído por Asmus e Guazelli (1981), Bacoccoli e Aranha (1984, apud Macedo 1991) e Macedo (1991) a efeito de compensação isostática entre a bacia em afundamento e a área continental em elevação e erosão e, portanto, passando a sofrer alívio de carga. A pulsos desse evento tectônico associa-se a retomada de fenómenos magmáticos, que resultaram nas intrusões basálticas na área centro-norte da bacia e alcalinas na região costeira e plataforma rasa atual.

Uma comprovação do soerguimento do continente é-nos dada por Vignol-Lelarge et al. (1994) que, utilizando o método dos traços de fissão em apatita em rochas do embasamento cristalino da Serra do Mar em área do Arco de Ponta Grossa (Fig. 4), concluíram que há 86 Ma a região sofreu um levantamento acompanhado de erosão da ordem de $2,5 \mathrm{~km}$. A esse levantamento atribuíram o soerguimento da Serra do Mar. Há a considerar, todavia, não ser essa a idade da serra na posição que ela hoje ocupa. O Arco de Ponta Grossa é um elemento tectônico com predisposição para o soerguimento desde o Triássico que, no Cretáceo Superior, foi submetido à maior elevação. Com a serra ocupando sua posição atual não poderia fornecer à borda da Bacia de Santos elásticos grossos como os que são encontrados na Formação Santos, pela distância de até uma centena de quilómetros que as separa.

O soerguimento progressivo da área continental (e, por consequência, da plataforma continental vizinha) foi também verificado por Gallagher et al (1994) ao comentarem a denudação e evolução topográfica na área do embasamento do sul-sudeste do Brasil, com base na análise de traços de fissão em apatita. Ela indicou que nos $50 \mathrm{~km}$ a partir da linha-decosta para o interior as idades são todas inferiores a $100 \mathrm{Ma}$ e tão baixas quanto 50-60 Ma, o aumento das idades dos traços de fissão crescendo muito rapidamente para o interior. Os dados que obtiveram sugerem ter havido mais de $3 \mathrm{~km}$ de denudação na planície costeira e possivelmente $1 \mathrm{~km}$ no interior. Uma proporção elevada de basalto Serra Geral constituiria parte do material removido pela erosão. Supomos que esse processo erosivo que, no final do Cretáceo Superior, levou ao desenvolvimento da superfície Japi, exumou o embasamento cristalino, com seus diques de diabásio e intrusões alcalinas, na área costeira adjacente à Bacia de Santos.

O divisor de águas entre as bacias de Santos e do Paraná devia então situar-se próximo àquela, possivelmente no sítio da atual plataforma média, a julgar pela natureza litológica da Formação Santos. A erosão seria muito mais intensa na vertente oceânica, de acentuado declive, que na continental. Esta drenava-se para o interior do continente, contribuindo para a sedimentação senoniana do Grupo Bauru (Campos 1905). Ao término do ciclo erosivo, na passagem do Cretáceo para o Terciário, constituiu-se a superfície de aplainamento Japi, que nivelou o Planalto Atlântico até esse divisor. A vertente marinha desse relevo recuou subparalelamente à borda da bacia, obedecendo aproximadamente, como hoje, às direções estruturais do embasamento pré-cambriano. Ao fazê-lo, entalhou as superficies Japi e neogênicas.

Faltam informações que permitam bem conhecer o reflexo, na plataforma, do importante evento tectônico iniciado no Paleoceno. Falhas têm sido nela assinaladas desde a década de 70; prováveis reativações de falhas do embasamento, que explicam a existência de desnivelamento local de planaltos, como a falha do Camburu (Campanha et al. 1992) na Serra do Juqueriquerê, próxima a São Sebastião, têm sido citados por vários autores como explicação para outras feições, regional ou localmente observadas.

Alves (1981) refere que, entre a zona de charneira que limita a parte profunda da Bacia de Santos e a linha-de-costa, existe um proeminente falhamento normal, a Falha de Santos, cujo rejeito é desconhecido por terem sido erodidas as possíveis camadas de referência do bloco elevado, o ocidental. Asmus e Ferrari (1978) sugerem que esta falha se tenha formado pelos mesmos processos ativos principalmente no Cenozóico, mas talvez desde o final do Mesozóico, que originaram as atuais serras do Mar e da Mantiqueira. Asmus (1981) informa que a falha foi inferida a partir de dados magnetométricos. A Falha de Santos não deve ser confundida com a falha situada junto à linha de charneira no trecho retilíneo E-W entre a Baía de Ilha Grande e Cabo Frio que corresponde, segundo Moriak \& Barros (1990), à acentuação do mergulho do embasamento rumo ao mar, estando associada localmente a falha bastante expressiva, cujo rejeito atinge "centenas de metros", quando se toma a superficie do embasamento como referência.

Parece-nos plausível supor que a atual Serra do Mar tenha surgido na Falha de Santos como resultado de abatimentos do planalto durante o magno evento tectônico iniciado no Paleoceno. Tal como se acham assinalados no Mapa Geológico do Brasil (Schobbenhaus et al 1981) parece provável que o arquipélago de Alcatrazes (Fig. 7) e as intrusões das rochas 


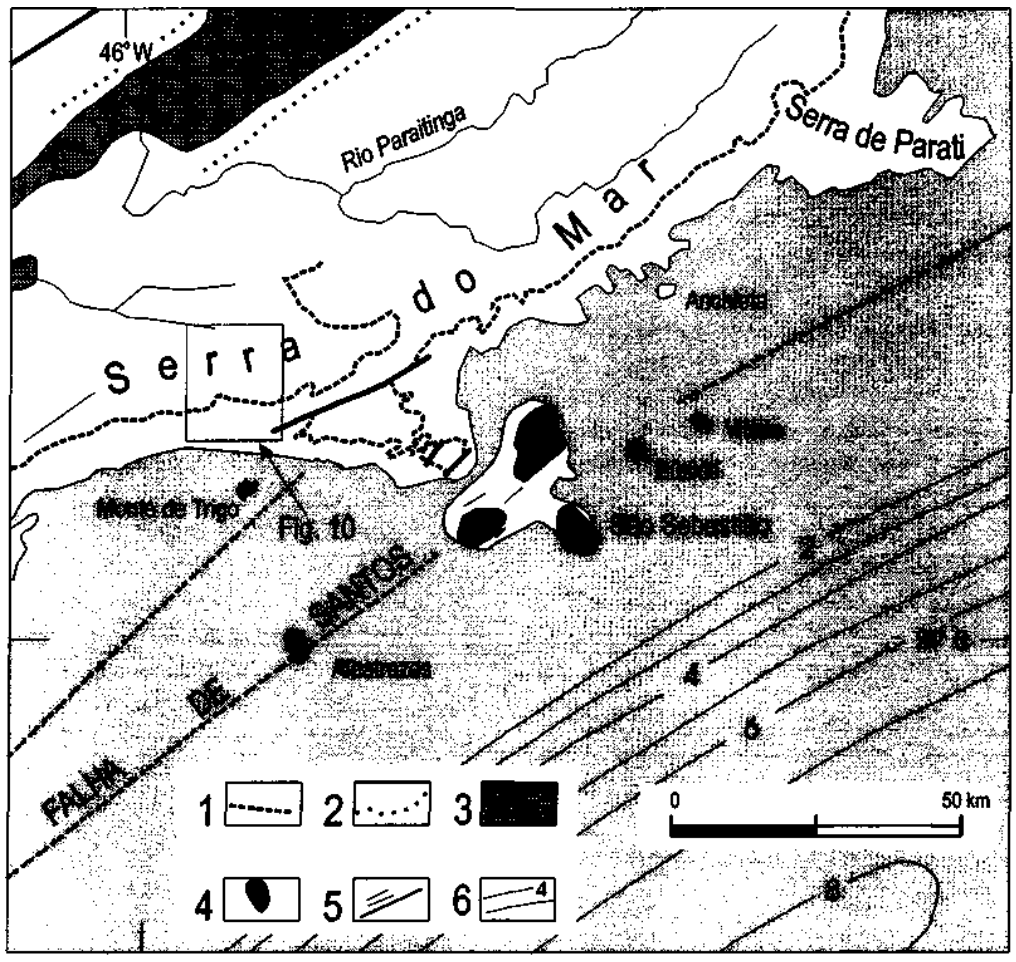

Figura 7-O grande promontório da Serra do Juqueriquerê e as principais ilhas costeiras do litoral norte paulista. Convenções: 1. Limite superior de escarpa, 2. Limites topográficos de riftes, 3. Bacias tafrogênicas, 4. Corpos alcalinos, 5. Alinhamentos estruturais e falhas, 6. Linhas de contorno estrutural do embasamento na área submersa

Figure 7 - The large promontory of the Juqueriquerê plateau and the principal islands of São Paulo northern coast. Legend: 1. Upper limit of scarp, 2. Topographic limits of rifts, 3. Taphrogenic basins, 4. Alkaline bodies, 5. Structural lineaments and faults, 6 . Basement structural contours in the submerged area

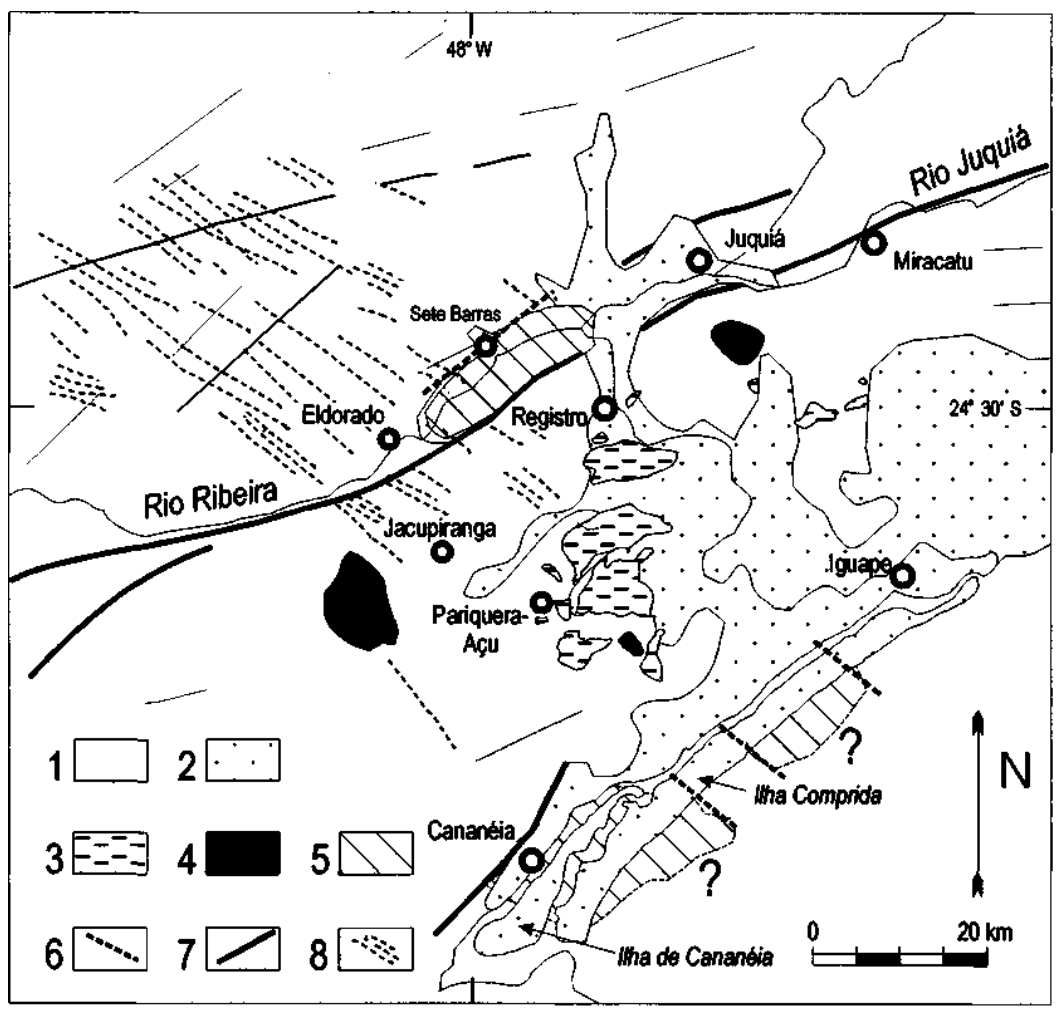

Figura 8 - Principais feições deprimidas no gráben de Cananéia, segundo Souza (1996) e disposição aproximada do gráben de Sete Barras. Convenções: 1. Embasamento, 2. Cobertura quaternária, 3. Formação Pariquera-Açu, 4. Coberturas de idade indeterminada 5. Corpos alcalinos, 6. Falha suposta, 7. Falha definida, 7. Diques

Figure 8 - Principal depressed features in the Cananéia Graben (according to Souza 1996) and aproximated location of the Sete Barras Graben. Legend: 1. Basement, 2. Quaternary cover, 3. Pariqüera-Açu Formation, 4. Cover of undefined age 5. Alkaline bodies, 6. Supposed fault, 7. Defined fault, 8. Dikes 
alcalinas das ilhas de São Sebastião, Búzios e Vitória, em disposição alinhada ao largo da costa de São Paulo, se situassem próximo a essa Serra do Mar ancestral. A intrusão das rochas alcalinas da ilha Monte de Trigo (Fig. 7) ter-se-ia igualmente processado no trecho do Planalto Atlântico hoje erodido. $\mathrm{O}$ mar terciário não poderia ter penetrado no gráben da Guanabara, pois ele ter-se-ia afundado no interior do Planalto Atlântico, pelo que seus sedimentos terciários são continentais.

A erosão da serra por ação de rios, mar e movimentos em massa de suas vertentes tê-la-ia feito recuar durante o Cenozóico, até três a quatro dezenas de quilómetros, abandonando numerosas ilhas e baixios próximo à costa atual, entalhando a superfície Japi e mais tarde as superfícies neogênicas. Não há evidências de quando se abriu o vale do rio Ribeira, interrompendo a continuidade da serra. A se confirmar a duvidosa idade miocênica inferior a média para a Formação Pariqüera-Açu (Lima \& Ângulo 1989, Melo et al. 1990a), depositada no baixo vale desse rio (Fig. 8), a serra já então havia recuado até posição próxima da atual.

$\mathrm{O}$ evento tectônico iniciado no Paleoceno foi muito importante e de ampla extensão, tanto na região sudeste do País como na bacia marginal. Lembre-se que Gonçalves et al. (1979) atribuíram uma idade paleocênica para a formação da charneira da bacia (Fig. 3), pela discordância erosiva do topo do Maastrichtiano.

Considere-se, todavia, que a hipótese ora aventada de recuo erosivo das encostas da Serra do Mar só poderá ser confirmada quando se dispuser de melhores conhecimentos sobre a Falha de Santos e, de modo geral, sobre a tectônica e sedimentação cenozóica da plataforma continental média e interna, diante da Serra do Mar.

\section{FEIÇÕES DA EVOLUÇÃO RECENTE DA SERRA}

DO MAR Os processos naturais no atual domínio da Serra do Mar, uma região submetida a altas pluviosidades médias anuais e episódios prolongados de chuvas, envolvem intensa participação de movimentações de massa. Os escorregamentos e deslocamentos de solos e rochas acontecem mormente ao longo de superfícies planas e inclinadas. As descontinuidades, como juntas e falhas antigas, são aproveitadas, pela água e pelos lentos processos de denudação associados, para desenvolver em profundidade as massas de solo e rocha decomposta que acabam sendo afetadas pela atividade erosiva incessante. A avaliação de instabilidade da Serra do Mar, bem como de outros terrenos submetidos à erosão acelerada, tem sido uma exigência, além de instrumento valioso para os estudos de prevenção e redução de desastres naturais.

Em Cubatão (SP), a Serra do Mar, situada próximo a importantes áreas urbanas e industriais, tem sido inadequadamente ocupada (nos chamados bairros-cota) e, por mais paradoxal que pareça, ainda tem sido objeto de insuficiente pesquisa para subsidiar o manejo ambiental. $\mathrm{O}$ quadro é agravado pela vegetação degradada, devido à incidência de chuva ácida provocada pela poluição atmosférica. A perda de proteção dos solos intensifica processos de rastejo, assim como os efeitos catastróficos de chuvas intensas periódicas, na forma de escorregamentos e outros movimentos de massa espalhados pelas íngremes encostas. O registro da coluna geológica quaternária costeira permite asseverar que os episódios mais recentes não são isolados, mas representam a continuidade de uma longa sucessão que, na maior parte, antecede a ocupação humana. Os estudos sobre a origem da serra podem auxiliar em muito o entendimento da dinâmica atual e subsidiar a formulação de critérios mais rigorosos de ocupação, gerenciamento de áreas de risco, planejamento de novas obras civis ou planos de conservação ambiental. Alguns desses aspectos, a seguir exemplificados, reforçam o interesse do estudo.
Paraná "A Serra do Mar não representa no Paraná apenas o degrau entre o litoral e o primeiro planalto do interior... mas constitui também uma serra marginal típica que se eleva de 500 a 1.000 m sobre o nível médio do planalto" (Maack 1968, p. 300).

Realmente, conforme salientado por Maack (1963), a serra no Estado do Paraná apresenta aspectos notáveis que a diferem dos que se mostram em São Paulo e no Rio de Janeiro. Entre a Serra do Mar e o litoral a região costeira do Paraná apresenta o Cinturão Granitóde Costeiro (B asei et al. 1992), em que se inclui o batólito Paranaguá (Basei et al. 1990). Constitui-se o cinturão de granitos mais ou menos foliados, granito-gnaisses, migmatitos e outras rochas foliadas com orientação principal dirigida a NE, que sustentam um relevo acidentado de morros e serras, que alcança $1.555 \mathrm{~m}$ de altitude na serra da Canavieira. Verifica-se que o fronte da Serra do Mar recuou da região de rochas laminadas para a faixa de stocks e batólitos de granitos alcalinos e peralcalinos (600-570 Ma apud Siga Jr. et al. 1997) tardi-orogênicos a anorogênicos (Kaul e Cordani 1994). A natureza petrográfica e estrutural desses granitos, frequentemente isótropos, tornam-nos resistentes à erosão, pelo que sustentam destacadas elevações, com altitudes de 1.500 a $1.889 \mathrm{~m}$ (na Serra da Graciosa).

Maack (op.cit.), que tão bem descreveu e figurou a Serra do Mar no Paraná, faz referências a superfícies de erosão desniveladas e basculadas por uma tectônica de falhas, assim como restos de antigos níveis de aplainamento truncando notavelmente as serras da Graciosa e Iquererim entre $1.400 \mathrm{e}$ $1.450 \mathrm{~m}$ de altitude, e elevações nas serras dos Castelhanos e Araraquara em níveis entre 1.200 e $1.250 \mathrm{~m}$, em forma de platôs e mesetas. Verifica-se que a superficie de aplainamento Purunã, tal como a do Japi em São Paulo e Rio de Janeiro, também foi afetada por deformações no Terciário.

Vale do RÏO Ribeira Várias causas provocaram a interrupção da Serra do Mar no litoral sul de São Paulo. Elas estão ligadas à abertura do vale do rio Ribeira de Iguape e à expansão de sua bacia pelo interior do Planalto Atlântico.

O Alinhamento de Guapiara (Fig. 4) é uma estrutura^alongada a NW que limita o Arco de Ponta Grossa a NE. É uma faixa caracterizada por intenso físsuramento e falhamentos que deram acesso ao magma basáltico eocretácico, à semelhança dos outros três grandes alinhamentos dos flancos do arco. O Alinhamento Estrutural de Guapiara (Ferreira 1981) ou Fissuramento de Guapiara (Algarte 1972) na verdade é uma faixa que tem pelo menos $600 \mathrm{~km}$ de extensão, $20 \mathrm{a} 100 \mathrm{~km}$ de largura e chega ao litoral na região de Iguape. Certamente se prolonga na plataforma continental, onde ainda não foi reconhecido, devendo estar coberto por sedimentação cenozóica. Exibe falhamentos normais, dirigidos segundo NW e NE. O Arco de Ponta Grossa foi ativo pelo menos desde o Triássico, mas teve seu maior soerguimento no Cretáceo Superior. No Neocomiano foi penetrado por extenso enxame de diques de diabásio orientados a NW (Fig. 8). Consideramos ter sido o arco o principal fator da abertura do vale do rio Ribeira. Outros fatores, porém, nela influíram.

O Cinturão Granitóide Costeiro do Estado do Paraná continua-se no sul de São Paulo, onde também existem os granitos alcalinos e peralcalinos pós-orogênicos que no Paraná sustentam a Serra do Mar. Formam as serras de Parateú e Mandira, nos lindes com o Paraná, e morros isolados na costa, como em Iguape e nas ilhas do Cardoso e Bom Abrigo, intrusivos no Cinturão Granitóide Costeiro. Não apresentam, contudo, expressão que lhes permita manter a continuidade da Serra do Mar, como o fazem no Paraná.

Outra causa da abertura do vale do Ribeira é chegarem à costa, e provavelmente se estenderem à plataforma continental, metassedimentos de fácies xisto-verde a anfibolito do Complexo Turvo-Cajati. Além desses fatos, o baixo vale do 
rio Ribeira (que recebe o nome de rio Ribeira de Iguape) sujeitou-se a movimentos tectônicos durante o Terciário. A Zona de Cisalhamento do Cubatão cruza a faixa do Alinhamento de Guapiara (Fig. 4) e, onde o faz, junto a ela se desenvolveu o gráben de Sete Barras (Melo et al 1989), com preenchimento de sedimentos continentais afossilíferos cuja espessura, entre 110 e $200 \mathrm{~m}$, determinada por sondagens elétricas verticais, indica que a base situa-se bem abaixo do nível do mar. Ele se limita por falhas normais dirigidas a NE e ENE. Melo et al. (1989) julgam possível que esses sedimentos tenham se depositado no Eoceno/Oligoceno. Pela análise de estruturas Melo et al. (1990a) concluíram que o gráben resultou de esforços principais trativos orientados a E-W e WNW-ESE, de falhas normais que cortam o embasamento e que não diferem significativamente das encontradas para esforços trativos definidos para a região das bacias de São Paulo e das drenadas pelo rio Paraíba do Sul, todos no quadrante NW. Sugerem tratar-se da mesma fase distensiva regional ocorrida no Paleógeno.

Movimentos de blocos realizados no Arco de Ponta Grossa, em ocasião ainda não datada, teriam levado à acumulação, no vale do rio Ribeira de Iguape, da Formação Pariqüera-Açu. Ela é continental, afossilífera, mas a suposta correlação dessa unidade a depósitos semelhantes (formações Alexandra no Paraná, Rio Claro e Pindamonhangaba em São Paulo) e as idades de discordâncias na Bacia de Santos levaram Melo et al. (1990b) a admitirem para ela idade eo- a meso-miocênica. Mioto (1984), considerando a sismicidade discreta da região, incluiu-a na que denominou Zona Sismogênica de Cananéia ou de Paranaguá, à qual seria relacionada a atividade do Arco de Ponta Grossa.

Outro fator que pode ter sido preponderante na interrupção da Serra do Mar no sul de São Paulo com a abertura do vale do rio Ribeira de Iguape foi a presença do gráben de Cananéia sob a planície costeira Cananéia-Iguape, recentemente admitida por Souza et al (1996). Traçando dois perfis paralelos convenientemente localizados no mapa Bouguer (Souza 1995) os autores obtiveram um modelo para o topografia do embasamento cristalino sob as ilhas Comprida e de Cananéia. Em cerca de metade sudoeste daquela e nesta última o embasamento acha-se deprimido até cerca de $500 \mathrm{~m}$ sob o nível do mar (Fig. 8), o que os levou a admitir a presença de um gráben ou meio-gráben orientado a NE. No decorrer dos anos 60 o antigo Instituto Geográfico e Geológico de São Paulo realizou duas sondagens na região, uma delas tendo penetrado $167 \mathrm{~m}$ de sedimentos continentais sem atingir o embasamento. Os $118 \mathrm{~m}$ inferiores constituem-se de sedimentos grossos, conglomerados e areias conglomeráticas, sotopostos a sedimentos marinhos e continentais da planície. Os dois perfis paralelos indicam uma inclinação dos blocos do embasamento para NW. Outro baixo gravimétrico existe próximo à cidade de Iguape, indicando a presença de quase $400 \mathrm{~m}$ de sedimentos, sendo os inferiores da mesma natureza grossa dos de Cananéia. Um alto entre esses dois baixos gravimétricos foi interpretado por Souza et al. (op. cit.) como extensão do lineamento de Guapiara. Esses autores correlacionaram o gráben com os desenvolvidos no Cenozóico na região sudeste do País. Supomos que os grábens de Sete Barras e Cananéia ter-se-iam originado no Planalto Atlântico durante o Paleógeno, que seria a idade da sedimentação que contêm. Deles, subsistem apenas as partes mais profundas.

A abertura do vale do rio Ribeira trouxe consequências catastróficas para o Planalto Atlântico. A posição da Serra do Mar como borda limite do planalto passou a ser desempenhada pela Serra de Paranapiacaba, bem mais para o interior da região. Essa serra é suportada pelo batólito granítico de Agudos Grandes. É nivelada a $1.200-1.300 \mathrm{~m}$ de altitude pela superficie de aplainamento Japi, que claramente se estende aos sedimentos devonianos da borda da Bacia do Paraná, pois junto à serra granítica nivela também as camadas da Formação Furnas, como na Serra das Furnas (PR), em altitudes próximas de $1.250 \mathrm{~m}$.

Com o recuo da borda do Planalto Atlântico para a Serra de Paranapiacaba ampla área de metamorfitos laminados do planalto ficou exposta à erosão regressiva. $\mathrm{O}$ rio Ribeira expandiu sua drenagem pelo primeiro planalto paranaense, capturando águas da superfície de erosão do Alto Iguaçu através do rio Açungui, a norte de Curitiba. Em São Paulo, a expansão da drenagem do rio Juquiá, afluente do Ribeira de Iguape, levou sua bacia a se estender até à superficie de erosão do Alto Tietê, na região a sul de Embu-Guaçu, transformando o que deveria ser originalmente a Serra do Mar em um simples divisor de águas de altitude decrescente, entre a drenagem costeira e a da bacia do Juquiá. Entretanto, antes de se interromper próximo à baixada do rio Ribeira de Iguape, volta a se elevar, atingindo $1.350 \mathrm{~m}$ de altitude na serra de Itatins, onde é suportada por rochas arqueanas de alto grau metamórfico, do Complexo Costeiro.

A Zona de Cisalhamento de Lancinha-Cubatão, ou simplesmente Falha do Cubatão, aproxima-se da região costeira, achando-se coberta pelos aluviões da drenagem do rio Preto a noroeste de Itanhaém. Dirige-se para a serra adiante de Santos, então bem caracterizada como Serra do Mar.

Cubatão O relevo escarpado que separa o Planalto Paulistano da Baixada Santista de há muito chamou atenção de geomorfólogos e geólogos, que nele julgaram ver um importante acidente tectônico. Martonne (1933), comparando-o à Serra Espinausse francesa, interpretou-o como resultante de um fraturamento em estreitos blocos de falha que teriam sofrido abatimento em direção à Baixada do Cubatão, com à consequente abertura de vales nos ângulos das falhas. $\mathrm{O}$ ilustre geógrafo francês não atentou devidamente à estrutura geológica da região, de resto então bem pouco conhecida. A grande falha transcorrente pré-cambriana do Cubatão, que atravessa todo o Planalto Atlântico no Estado de São Paulo, com o recuo erosivo do fronte serrano foi alcançada pela erosão remontante do rio Cubatão. A falha, na região, põe em contato rochas de diferentes resistências à erosão: metassedimentos que incluem filitos, metacalcários, xistos e quartzitos no bloco norte, e um complexo gnáissico-migmatíticogranítico a sul. Em seu recuo erosivo a escarpa alcançou a falha e por ela se estendeu para oeste, separando a Serra do Pai Matias da escarpa principal (Fig. 9). Um seu afluente, o rio Moji, teve idêntico desenvolvimento, acompanhando a falha para leste e separando a Serra do Morrão da escarpa do Cubatão. Também o rio Branco, afluente do rio Preto, mais para oeste, isolou a Serra de Mongaguá, em parte suportada por granitos e migmatitos (Almeida 1953). Sadowski (1974), em seu estudo sobre a Serra do Cubatão, não encontrou evidências de que as grandes escarpas tenham resultado de movimentos recentes da Falha do Cubatão ou de outras da região.

É importante observar que a Serra do Quilombo, a sul da Falha do Cubatão, sustentada por granito isótropo cambro-ordoviciano que penetrou migmatitos do Complexo Costeiro, eleva-se à mesma altitude dos testemunhos da superfície Japi no planalto (Fig. 9), evidenciando que a falha não registra deslocamentos verticais entre os blocos que separa, não sendo assim responsável pela origem da escarpa da Serra do Mar na região. De resto, no interior do planalto atravessado pela falha a nordeste da estação ferroviária de Paranapiacaba, não se nota desnivelamento do relevo causado por ela. Também o canal de Bertioga, entre a ilha de Santo Amaro e o bloco costeiro, aloja-se em uma falha antiga que separa unidades litológicas diversas do Complexo Costeiro. Com o nível do mar mais baixo que hoje a erosão escavou ao longo dela a depressão ocupada pelo canal. 


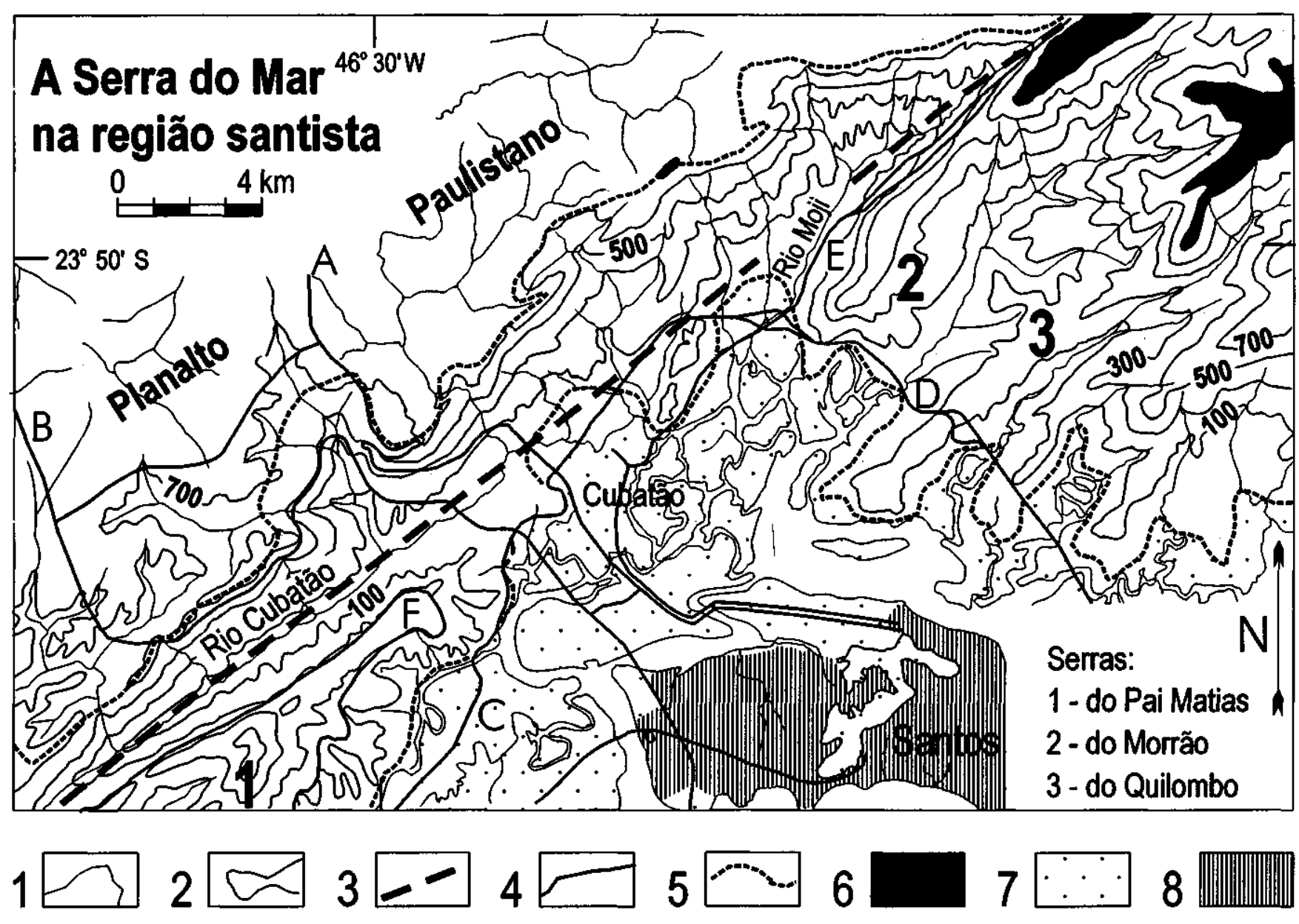

Figura 9-A Serra do Mar na região santista (atualizado de Almeida J 953). Convenções: 1. Rede de drenagem, 2. Curva de nível, 3. Falha, 4. Estradas: A. Via Anchieta, B. Rodovia dos Imigrantes, C. Rodovia Pé. Manoel da Nóbrega, D. Rodovia PiaçagüeraGuarujá, E. Rede Ferroviária Federal S. A., F. Ferrovias Paulistas S. A., 5. Limite de unidades geomorfológicas, 6. Cotas superiores a 900 m, 7. Cobertura cenozóica, 8. Area urbana

Figure 9 - The Serra do Mar in the Santos region (updated from Almeida 1953). Legend: 1. Drainage network, 2. Topographic contours, 3. Faults, 4. Main roads: A. Anchieta, B. Imigrantes, C. Padre Manoel da Nóbrega, D. Piaçagüera-Guarujá, E. Rede Ferroviária Federal, F. Ferrovia Paulista, 5. Geomorphologic limits, 6. Heights abo vê $900 \mathrm{~m}, 7$. Cenozoic cover, 8. Urban área

Há certos trechos da Serra do Mar em que ela vem seccionando superfícies de erosão neogênicas cuja drenagem provinha originalmente de áreas do Planalto Atlântico hoje já desaparecidas com o recuo erosivo da serra. Um claro exemplo parece situar-se na borda do planalto a norte de Bertioga (SP). Entre o rio Tietê e uma área drenada para a costa pelo rio Itatinga a SSE de Mogi das Cruzes, um divisor de águas é suportado por uma faixa de granitos sintectônicos e migmatitos, limitada a norte pela Zona de Cisalhamento de Cubatão. A área drenada para o rio Tietê preserva bem claros os indícios da superfície de erosão do Alto Tietê, que se ergueu até cerca de $950 \mathrm{~m}$ de altitude nos granitos. O rio Jundiaí faz parte das cabeceiras do rio Tietê. A sul desse divisor, a bacia do rio Itatinga vem se expandindo no planalto, destruindo a superfície do Alto Tietê, sustentada por migmatitos, com pequenos corpos isolados de granitos. Essa área é atravessada pela Falha de Jurubatuba ou dos Freires e suas ramificações (Fig. 10).

A superfície do Alto Tietê acha-se ali bem mais entalhada que a norte do referido divisor e seus rios são muito mais adaptados às estruturas, sobretudo a falhas. $\mathrm{O}$ eixo principal de drenagem é o médio curso do rio Itatinga e seu prosseguimento para o divisor de águas, o rio Claro. Seu traçado dirigido a NW parece refletir fraturas assim orientadas. Ao ser atravessado por uma falha orientada aproxi- madamente a $30^{\circ} \mathrm{NE}$, provável ramificação da dos Freires, esse eixo recebe, quase no mesmo local, dois afluentes. Pela margem direita vem ter o rio a que os mapas atribuem o nome de Itatinga, por ser mais extenso que o rio Claro. Ele forma um vale deprimido cerca de 200-300 m abaixo das cristas locais dominantes e acha-se claramente adaptado à Falha dos Freires, especialmente em seu alto curso, onde esta apresenta distinta faixa de rochas cisalhadas. À margem esquerda do referido eixo de drenagem, seguindo a mesma direção N30E, vem ter o rio Grande, procedente do divisor de águas granítico. A Serra do Mar em seu recuo interceptou o rio Itatinga, que se precipita em canyon para a planície costeira, onde desagua no rio Itapanhaú. Ó eixo de drenagem rio Claro - médio rio Itatinga antecedeu o posicionamento atual da serra (Fig. 10), não se podendo saber qual seu destino no trecho hoje erodido do planalto. $\mathrm{O}$ declive de quase $700 \mathrm{~m}$ entre o médio trecho do rio Itatinga no planalto e a planície costeira foi aproveitado para construção de pequena usina hidrelétrica, homónima.

A influência dos diversos tipos rochosos no comportamento das encostas foi investigada em escala de detalhe por Pires Neto et al. (1979), na região dos morros de Santos e São Vicente. Os padrões de erosão diferencial ali descritos podem ser em grande parte comuns a outros trechos da Serra do Mar. Rochas anisotrópicas, como migmatitos de melanossoma xis- 
toso (referidos como de paleossoma dominante) constituem "as partes mais rebaixadas do relevo", assim como falhas e zonas de cisalhamento espessas. Reativações de falhamentos antigos foram identificadas, configurando escarpas de linhade-falha, como ao longo de zona de cisalhamento NE retilínea da região do Morro do Marapé (Santoro et al. 1979). Granitóides embrechíticos e rochas graníticas equigranulares isótropas compõem as elevações regionais. O principal contraste entre esses dois grandes grupos de rochas reside na foliação marcante dos embrechitos, que condiciona a orientação das cristas, enquanto nos granitos não-foliados predominam as formas dômicas, as altitudes mais elevadas e os topos arredondados.

São Sebastião O cimo da Serra do Mar continua para leste, suportado por migmatitos variados do Complexo Costeiro, e é nivelado a cerca de $800 \mathrm{~m}$ de altitude pela superficie de erosão do Alto Tietê. Do ribeirão Guaratuba até a Serra do Juqueriquerê a Serra do Mar passa a se apoiar em rochas granitóides sintectônicas, com o que seus cimos subnivelados se elevam a $1.200-1.300 \mathrm{~m}$, que é a altitude do divisor de águas das bacias dos rios Tietê e Paraibuna no planalto, próximo à serra.

A genericamente denominada Serra do Juqueriquerê avança em promontório em direção à ilha de São Sebastião. Campanha et al. (1994) realizaram estudos geológicos e morfotectônicos dessa serra, dos mais detalhados já feitos na Serra do Mar. Distinguiram um bloco mais elevado, a 1. 150 - 1.300 $\mathrm{m}$ de altitude, de composição granítica, adjacente a outro, constituído de gnaisses e migmatitos e deprimido em relação àquele por seu subnivelamento entre $900-950 \mathrm{~m}$ de altitude. Seu limite retilíneo com o degrau mais baixo coincide com a falha pré-cambriana de Camburu. É esta uma zona de cisalhamento dúctil com dezenas a centenas de metros de largura de rochas miloníticas. Este degrau foi chamado Planalto do Juqueriquerê (Ponçano et al. 1981). Suas rochas, que são migmatitos paraderivados, são divididas em blocos menores por numerosas pequenas falhas, que seriam responsáveis pelo abatimento de cerca de $300 \mathrm{~m}$ em relação ao degrau anterior, tendo o movimento diferencial maior se processado na falha de Camburu.

Face à falta de sedimentos datáveis, sugeriram os referidos autores correlação desses níveis com superficies morfológicas que se conhecem na região, assim como discordâncias na coluna estratigráfica da Bacia de Santos. A superfície mais alta correlacionaram à do Japi que, por coincidência ou não, tem idêntica altitude que os anéis externos dos stocks alcalinos da ilha de São Sebastião. O patamar intermediário, constituído de rochas mais facilmente erodidas que as graníticas do planalto cimeiro, seria resto de uma superfície de erosão mesomiocênica, que foi em parte tectonicamente deprimida no Neomioceno para formar o Planalto de Juqueriquerê. A resistência à erosão oferecida pelas intrusões alcalinas em granitos laminados da ilha de São Sebastião vem retardando o recuo da Serra do Mar e originando a formação do destacado promontório constituído pela Serra de Juqueriquerê com seus degraus e também pela ilha, do qual esta geograficamente participou antes da transgressão Flandriana. Constitui uma prova de que a Serra do Mar esteve inicialmente bem além da posição em que hoje se situa, sendo o seu recuo basicamente devido à erosão.

Parati A Serra do Mar no trecho compreendido entre as serras do Juqueriquerê e do Parati (Fig. 7) é um relevo escarpado, com altitudes de 800 a $1.000 \mathrm{~m}$, em que termina o planalto do Paraitinga-Paraibuna. E constituída de rochas granitóides, sobretudo variedades de migmatitos com foliação a NE - ENE. Em seu sopé, a partir de cerca de $20 \mathrm{~km}$ para ENE de Caraguatatuba, apresenta-se uma faixa de rochas granulíti- cas, principalmente charnockitos, que se dirige para SE, às faldas da Serra do Parati, até Piçanguaba.

A Serra do Parati (Fig. 7) constitui a maior parte de um promontório avançado para $\mathrm{SE}$, separando as baías de Ilha Grande e Ubatumirim. Seu ponto mais alto, o pico do Cuscuzeiro, alcanca $1.426 \mathrm{~m}$ acima do nível do mar. É suportada por um grande stock de granito isótropo, pós-tectônico, do Eopaleozóico (Cordani e Kawashita, 1971). Duas falhas transcorrentes pré-cambrianas perlongam a Serra do Mar e seu reverso. Melo e Pires Neto (1977) interpretaram as escarpas da serra nesse trecho como resultado de abatimentos e basculamentos de blocos de falha. Dada a continuidade topográfica da Serra do Parati com o planalto, parece-nos mais provável que elas representem o fronte de erosão remontante da borda do planalto entre os dois maciços resistentes dos promontórios sustentados pelas rochas alcalinas da ilha de São Sebastião e o granito do Parati.

A Serra da Bocaina é um típico conjunto de planaltos elevados, embora desnivelados entre si (ver Fig. 4.3 de Ponçano et al 1981), que se situa entre o vale do rio Paraíba do Sul a norte e nordeste e o Planalto do Paraitinga-Paraibuna a oeste. Seu relevo montanhoso inclina-se para o litoral a sul, terminando nas escarpas erosivas da Serra do Mar, elevadas de uns $1.000 \mathrm{~m}$ diante da baía da Ilha Grande.

O limite norte da Serra da Bocaina relaciona-se ao tectonismo por falhas do gráben do Paraíba, sem que se conheçam detalhes. E possível que o planalto da Bocaina seja resíduo de erosão de abaulamento em que se deprimiu o gráben, pois sua altitude a norte, em torno de 1.800-2.000 m, é a mesma que a da Serra da Mantiqueira do outro lado do gráben, abstraindose naturalmente o relevo dos maciços de Itatiaia e Passa-Quatro. A drenagem longitudinal do Planalto do ParaitingaParaibuna, favorecida pelas estruturas pré-cambrianas predominantemente orientadas a ENE, teria grandemente facilitado o recorte erosivo dessa elevação, como ainda hoje se observa no flanco ocidental da Bocaina onde se situam os cursos d'água formadores do rio Paraitinga.

O planalto da Bocaina tem uma extensão para leste, o elevado espigão, em parte granítico, da Serra da Carioca, que o vale do rio Piraí separa da Serra das Araras. Entre elas se estabeleceu o colo de Lídice (550 m de altitude), que permite à rodovia e à ferrovia provenientes de Angra dos Reis, no litoral, transporem a Serra do Mar numa altura relativamente pouco elevada, para alcançarem Barra Mansa, às margens do rio Paraíba do Sul.

RÍO de Janeiro $\mathrm{O}$ médio vale do rio Paraíba do Sul apresenta, entre Barra Mansa e Barra do Piraí, nas áreas de rochas pré-cambrianas, um relevo de colinas arredondadas do tipo chamado "mar-de-morros", cujos cimos se mostram em altitudes próximas de $500-550 \mathrm{~m}$. Definem um nível de erosão em que se encaixa o rio ( $358 \mathrm{~m}$ de altitude em Barra do Piraí). Esse nível continua-se pela bacia do rio Piraí e cercanias da represa do Ribeirão das Lajes. Essa superfície de erosão estende-se até à borda do planalto, onde é truncada pelas escarpas em recuo da Serra das Araras, nome local da Serra do Mar, e que responde por seu subnivelamento local, Esse recuo causou a captura do ribeirão das Lajes (hoje represado), desviando para o mar, pelo rio Guandu, as águas que antes fluiam para o rio Piraí.

O gráben da Guanabara formou-se no Paleoceno no interior do Planalto Atlântico. Nessa ocasião este se estendia bem mais para sudeste, até a Serra do Mar que, como supomos, se elevou na mesma ocasião junto à Falha de Santos. $\mathrm{O}$ recuo erosivo de suas escarpas durante meia centena de milhões de anos fez com que se aproximasse da borda sul do gráben, desfazendo-a em morros e serras que constituem os Maciços Litorâneos: a Ilha Grande e a de Sepetiba; as serras da Carioca e Niterói, e mais para leste, outras serras e morros costeiros. Alcançam altitudes de cerca de $1.000 \mathrm{~m}$ a oeste, mas de Niterói para leste 


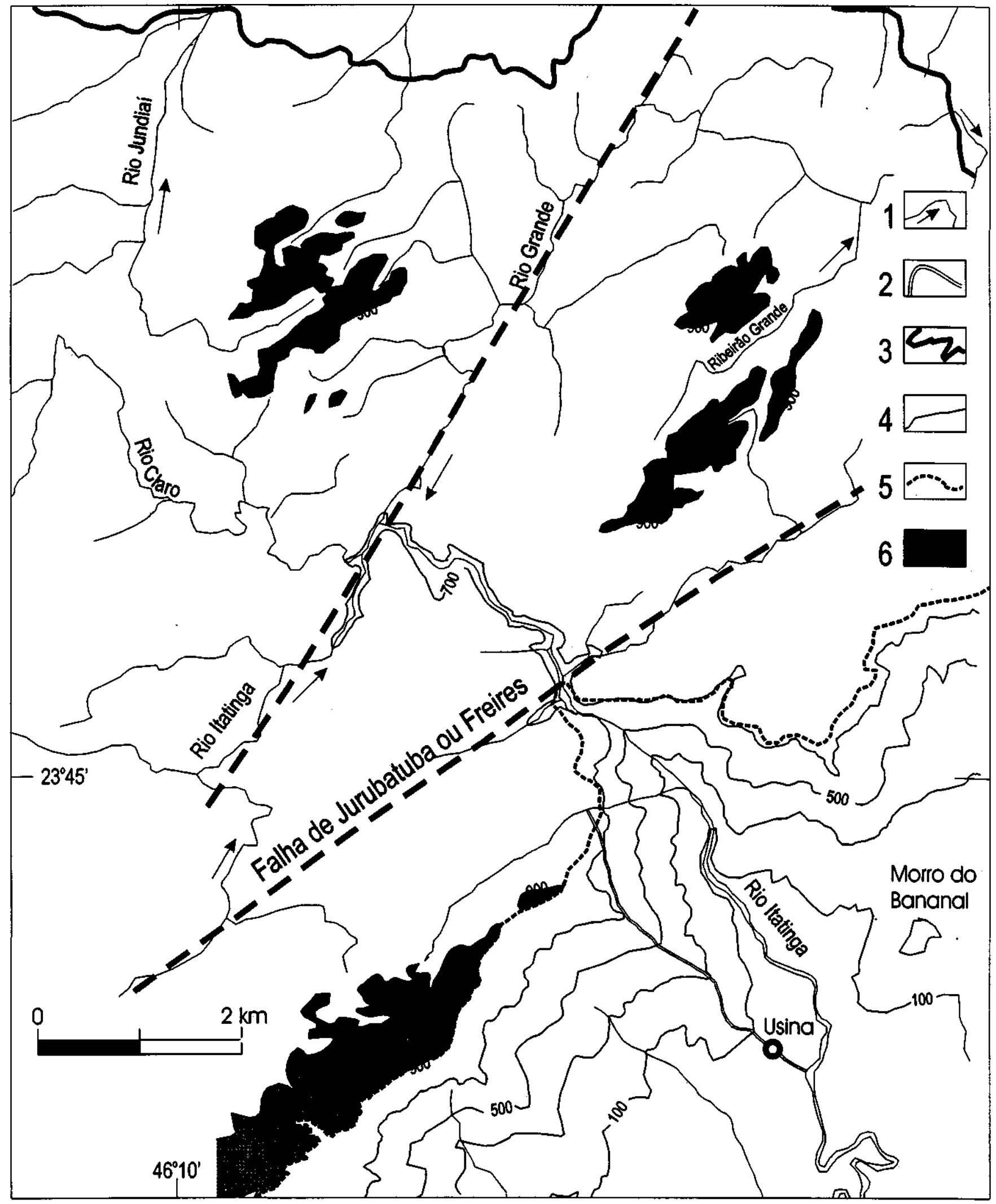

Figura 10 - Área de planalto drenada diretamente para o mar: bacia do rio Itatinga, entre Mogi das Cruzes e Bertioga. Ilustração baseada em mapas na escala 1:50 000 do IGG, respectivamente folhas Bertioga SF.23-Y-D-IV-4, 1971, e Mogi das Cruzes SF.23-Y-D-IV-2,1972. Convenções: 1. Rede de drenagem, com sentido defluxo, 2. Adutora, 3. Estrada, 4. Curva de nível, 5. Limite superior de escarpa da serra, 6. Cotas superiores a $900 \mathrm{~m}$

Figure 10 - Planaltic área with drained towards the sea: Itatinga ri ver basin, between Mogi das Cruzes and Bertioga. Based on IGG maps at the 1:50 000 scale, respectively Bertioga SF.23-Y-D-IV-4, 1971, and Mogi das Cruzes SF.23-Y-D-IV-2, 1972. Conventions: 1. Drainage network, with flow sense, 2. Aqueduct, 3. Roads, 4. Topographic contours, 5. Upper limit of scarp, 6. Heights above $900 \mathrm{~m}$ 
tornam-se mais baixos. São considerados como restos de blocos de falha basculados para o interior do gráben (Ruellan, 1944). Durante estágio de rebaixamento generalizado do nível do mar desenvolveu-se em seu interior um sistema de drenagem que escoou para o mar por um rio que passava na atual entrada da baía de Guanabara, o rio de Janeiro. A transgressão Flandriana inundou parte dessa bacia hidrográfica, formando uma ria, a baía de Guanabara (Ruellan 1944). Foram igualmente inundadas as baías de Sepetiba e Ilha Grande, orladas pelas escarpas da Serra do Mar, assim como o canal de São Sebastião e o paleo-vale fluvial que se inicia em sua entrada sul dirigindo-se para SE (Furtado et al. 1996).

Ferrari (1990) sintetizou com precisão as características da região centro-ocidental do gráben e indicou que a Serra do Mar da região de Itacuruçá ruma para NE, seguindo pela Serra das Araras. Assinala os limites erosivos dos blocos afundados até alcançarem a Serra dos Órgãos, acompanhando assim o limite norte do gráben da Guanabara.
A Serra dos Órgãos foi reconhecida por Ruellan (1944) como um bloco falhado inclinado para o norte (Fig. 2), com falhas a NNE, o que foi posteriormente confirmado. Constitui-se de um batólito com cerca de $100 \mathrm{~km}$ de extensão, de rochas graníticas e ortognáissicas sintectônicas do Pré-Cambriano Superior, intrudidas por granitos pós-tectônicos eopaleozóicos (Ledent \& Pasteels 1968, Cordani et al. 1973). A Serra do Mar para leste da Serra dos Órgãos torna-se descontinuada, mas o nome tem sido aplicado às serras situadas à margem esquerda do rio Imbé, a sul de São Fidélis.

Finalmente, é justo lembrar que o geólogo e geomorfólogo J. L. Rich (1953), após visitar a serra no Rio de Janeiro, São Paulo e Paraná, sobrevoá-la e examinar aerofotos, declarou não ter visto indícios de falhas recentes que seriam causadoras das escarpas. Sugeriu um arqueamento, que teria elevado o continente, associado a um afundamento da região costeira, o primeiro fornecendo material para a depressão e restabelecendo-se de tal modo o equilíbrio isostático.

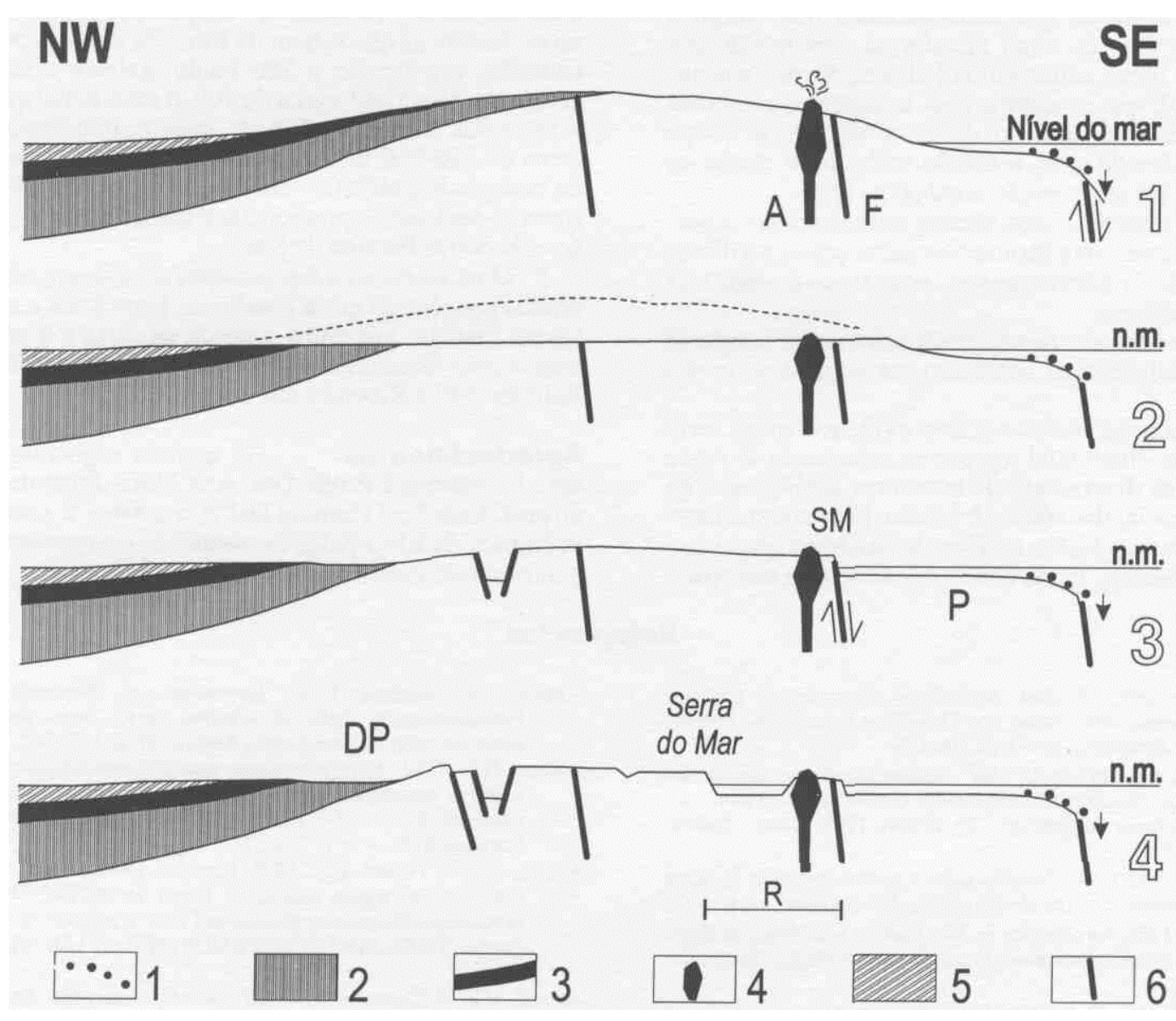

Figura 11- Esquema da origem e recuo erosivo da Serra do Mar, na região entre a Bacia do Paraná, no continente, e a Bacia de Santos, a sudeste. Estágios: 1. Soerguimento senoniano erodido, causando deposição nas bacias de Santos e do Paraná. Depósitos da Formação Santos indicados na primeira e do Grupo Bauru na segunda. Vulcanismo alcalino (A); Falha de Santos (F). 2. Desenvolvimento da superficie de aplainamento Japi no final do Senoniano. 3. Deformação da Superficie Japi no Paleoceno. Surge a Serra do Mar (SM) na Falha de Santos (F), o sistema de grábens continentais e começa a se desenvolver, na costa, a plataforma continental (P). 4. Recuo erosivo (R) da Serra do Mar para sua posição atual. A posição esquemática da Depressão Periférica e indicada (DP). Intrusões alcalinas sustentam ilhas. Convenções: 1. Depósitos da Fm. Santos, 2. Cobertura fanerozóica sotoposta ao basalto Serra Geral, 3. Formação Serra Geral, 4. Corpos alcalinos, 5. Grupo Bauru, 6. Falhas

Figure 11 - Schematic diagram of the origin and erosional SE-NW retreat of the Serra do Mar, in the region between the inland Paraná Basin, and the Santos Basin. Stages: 1. Eroded Senonian uplift, allowing deposition in both basins. Santos Formation deposits indicated in the later and Bauru Group in the former. Alkaline volcanism (A); Santos Fault (F). 2. Development of the Japi Erosional Surface at the end of Senonian. 3. Paleocene deformation of the Japi Surface. The Serra do Mar (SM) is generated at the Santos Fault $(\mathrm{F})$, the system of continental rifts is originated and the continental platform is formed in the coast $(\mathrm{P})$. 4. Erosional retreat (R) of the Serra do Mar towards its present position. The aproximate position of the Depressão Periférica is indicated (DP). Alkaline intrusions sustain islands. Conventions: 1. Santos Formation deposits, 2. Phanerozoic cover beneath the Serra Geral basalt, 3. Serra Geral Formation, 4. Alkaline bodies, 5. Bauru Group, 6. Faults 
CONCLUSÕES Este trabalho mostra uma aceitável correlação entre os fatos geológicos e geomorfológicos ora conhecidos e as inferências relativas à evolução pós-turoniana da região compreendida entre a Bacia de Santos, a região costeira, a Serra do Mar na posição que hoje ocupa e os planaltos de seu reverso, com o sistema de riftes ali instalados.

As superfícies de aplainamento Japi e Alto Tietê, sobretudo pela extensão que os vestígios daquela ocupam na região sudeste do País, forçosamente se continuavam mais para leste que o indicam seus indícios no nivelamento dos cimos da Serra do Mar. Consideramos a superfície Japi como término de um processo erosivo que arrasou o relevo surgido com o soerguimento senoniano realizado na plataforma continental e região adjacente do continente. Os detritos dessa erosão foram levados para a borda da plataforma (formações Santos, Juréia e Itajaí-Açu) e para o interior do País (Formação Bauru).

O importante evento tectônico iniciado no Paleoceno, que causou a deformação por flexuras e falhamentos da superficie Japi dando origem às bacias tafrogênicas do sudeste e a Serra da Mantiqueira, supomos que também tenha feito surgir a Serra do Mar na área da atual plataforma continental, por soerguimento do bloco ocidental da Falha de Santos e abatimento do oriental, que se cobriu com sedimentos marinhos cenozóicos. Sugerimos que no decorrer de três a quatro dezenas de milhões de anos a erosão tenha feito recuar as

É apresentada uma descrição sucinta dos principais aspectos geológicos, tectônicos e geomorfológicos que se verificam em toda a extensão da serra e que nos conduziram às seguintes conclusões e inferências:

1 - A Serra do Mar não denota evidências de ter resultado de importantes falhamentos neotectônicos ocorridos em seu sítio atual.

2 - A análise das estruturas e relevo evidencia que a serra resultou de erosão diferencial regressiva, adaptando-se nesse processo à extrema diversidade de estruturas geológicas e de resistência diferencial das rochas à erosão, bem como à morfotectônica que se manifestou no Planalto Atlântico durante o Paleógeno e o Mioceno. Essas condições causaram a abertura encostas da serra até sua posição atual (Fig. 11).

do vale do rio Ribeira, sobretudo pela presença do Alinhamento de Guapiara; as características peculiares da serra granítica no Estado do Paraná; a persistência de promontórios sustentados por intrusões de rochas graníticas e alcalinas; as numerosas ilhas abandonadas durante seu recuo para formar a plataforma continental rasa atual; o peculiar relevo que se apresenta na região costeira e o desvio da serra para o interior, no Rio de Janeiro, estabelecendo-se próximo à borda norte do gráben da Guanabara.

3 - Com o recuo erosivo das encostas da serra para oeste, estas vieram seccionando superfícies de erosão do planalto, que determinam frequentemente o subnivelamento de seus cimos. Rios do planalto foram decapitados, como no recuo da Serra do Cubatão (SP), ou capturados, como o ribeirão das Lajes (RJ), ou ainda a drenagem que se faz do planalto para o mar foi seccionada, como a dos rios Itatinga (SP) e cabeceiras do rio Itapanhaú (SP).

4 - Nos sítios em que as superfícies neogênicas estão sendo truncadas pelas escarpas em regressão apresentam-se locais mais baixos que facilitam a transposição rodo-ferroviária da serra. Assim, as que sobem da Baixada Santista pela Serra do Cubatão, em direção a São Paulo, galgam a superfície de erosão do Alto Tietê, cerca de $400 \mathrm{~m}$ mais baixa que a do Japi; a Serra das Araras, no Rio de Janeiro, intercepta o nível de cerca de 500-550 m de altitude do relevo de mar-de-morros da bacia hidrográfica do rio Piraí e de seu antigo afluente, o ribeirão das Lajes, e propicia fácil acesso de ferrovia e rodovia ao vale do rio Paraíba do Sul.

5 - O recuo erosivo das escarpas entalhando superficies de erosão neogênicas criou condições favoráveis a represamentos no planalto próximos à borda da serra e à instalação de usinas hidrelétricas em seu sopé. Tais são as de Cubatão (SP), Itatinga (SP) e Ribeirão das Lajes (RJ).

Agradecimentos Os autores registram profundos agradecimentos à Profa. Dra. Ana Maria Pimentel Mizusaki, ao prof. Luiz José Homem Del'Rey e Silva e a dois revisores anónimos da RBG pelos comentários e sugestões que muito contribuíram para o melhoramento do texto.

\section{Referências}

Ab'Saber, A.N.; Bigarella, J.J. 1961. Superfícies aplainadas do primeiro planalto do Paraná. Associação dos Geógrafos Brasileiros, Boletim Paranaense de Geografia, n. 4/5, p. 116-125.

Algarte, J.P. 1972. A influência dos arqueamentos cratônicos no condicionamento das alcalinas nos estados de São Paulo e Paraná. In: Congresso Brasileiro de Geologia, 26, Belém, 1972. Anais... Belém, SBG. v. 2, p. 65-69.

Almeida, F.F.M. de. 1953. Considerações sobre a geomorfogênese da Serra de Cubatão. Boletim Paulista de Geografia, São Paulo, v. 15, p. 3-17.

Almeida, F.F.M. de. 1955. As camadas de São Paulo e a tectônica da Serra da Cantareira. Boletim Sociedade Brasileira de Geologia, São Paulo, v. 4, n. 2 , p. $23-40$

Almeida, F.F.M. de. 1958. O Planalto Paulistano. In: Azevedo, A. de. $A$ cidade de São Paulo. São Paulo, v. 1, p. 113-167. (v. 1, A Região de São Paulo)

Almeida, F.F.M. de. 1964. Fundamentos geológicos do relevo paulista. In: Instituto Geográfico e Geológico. Geologia do Estado de São Paulo. São Paulo: IGG. p. 167-263. (IGG. Boletim, 41)

Almeida, F.F.M. de. 1976. The system of continental rifts bordering the Santos Basin, Brazil. Anais da Academia Brasileira de Ciências, v. 48 (supl.), p. 15-26. (Proceedings of the International Symposium on Continental Margins of Atlantic Type, October 1975).

Almeida, F.F.M. de; Brito Neves, B.B. de; Carneiro, C.D.R. 1997. Origin and evolution of the South-American Platform. Earth-Science Reviews (submitted).

Alves, E.C. 1981. Estrutura da margem continental brasileira e das áreas oceânicas e continentais adjacentes. In: PETROBRÁS. Estruturas e tectonismo da margem continental brasileira, e suas implicações nos processos sedimentares e na avaliação do potencial de recursos minerais; relatório final. Rio de Janeiro, PETROBRÁS/CENPES/ DINTEP.p. 187-269. (Projeto REMAC 9).
Amaral, G.; Cordani, U.G.; Kawashita, K. Reynolds, J.H. 1967. Potassium-argon ages of alkaline rocks from southern Brasil. Geochimica et Cosmochimica Acta, n. 31. p. 117-142.

Asmus, H.E. 1981. Relacionamento genético das feições geológicas da margem continental sudeste brasileira e da área continental emersa adjacente. In: Simpósio Regional de Geologia, 3, Curitiba, 1981. Atas... Curitiba, SBG. v. 1, p. 262-273.

Asmus, H.E. \& Ferrari, A.L. 1978. Hipótese sobre a causa do tectonismo cenozóico na região sudeste do Brasil. In: PETROBRÁS. Aspectos estruturais da margem continental leste e sudeste do Brasil. Rio de Janeiro, PETROBRÁS/CENPES/DINTEP. p.75-88. (Projeto REMAC 4).

Asmus, H.E. \& Guazelli, M. 1981. Descricão sumária das estruturas da margem continental brasileira e das áreas oceânicas e continentais adjacentes, hipóteses sobre o tectonismo causador e implicações para os prognósticos de recursos minerais. In: PETROBRÁS. Estruturas $e$ tectonismo da margem continental brasileira, e suas implicações nos processos sedimentares e na avaliação do potencial de recursos minerais; relatório final. Rio de Janeiro, CENPES/DINTEP. p. 187-269. (Projeto REMAC 9).

Bacoccoli, G. \& Aranha, L.G.F. 1984. Evolução estrutural fanerozóica do Brasil Meridional. Rio de Janeiro: PETROBRÁS. (Relatório Interno).

Basei, M.A.S.; Siga Jr., O.; Reis Neto, J.M. dos 1990.0 batólito Paranaguá: proposição, idade, considerações petrogenéticas e implicações tectônicas. In: Congresso Brasileiro de Geologia, 36, 1990, Natal. Anais... Natal: SBG. v. 4, p. 1684-1699.

Basei, M.A.S.; Siga Jr., O.; Machiavelli, A.; Mancini, F. 1992. Evolução tectônica dos terrenos ente os cinturões Ribeira e Dom Feliciano (PR-SC). Revista Brasileira de Geociências, v. 22, n. 2, p. 216-221.

Campanha, G.A.da.; Ens, H.H.; Ponçano, W.L. 1994. Análise morfotectônica do Planalto do Juqueriquerê, São Sebastião. Revista Brasileira de Geociências, v. 24, n. 1, p. 32-42. 
Campos, L.F.G. 1905. Reconhecimento da zona compreendida entre Bauru e Itapura. São Paulo: Estrada de Ferro Noroeste do Brasil. 40p.

Carneiro, C.D.R.; Bistrichi, C.A.; Ponçano, W.L.; Almeida, M.A. de.; Almeida, F.F.M de.; Santos, M.C.S.R dos 1981. Mapa Geomorfológico do Estado de São Paulo, ao milionésimo. São Paulo: IPT. (IPT. Monografias 5, anexo).

Cordani, U.C.; Delhal, Ledent, D. 1973. Orogenéses superposées dans lê précambrien du Brésil sud-oriental (États de Rio de Janeiro et de Minas Gerais). Revista Brasileira de Geociências, v. 3, n. 1, p. 1-22.

Cordani, U.G. \& Kawashita, K. 1971. Estudo geocronológico pelo método $\mathrm{Rb}-\mathrm{Sr}$ de rochas graníticas intrusivas no Grupo Açungui. In: Congresso Brasileiro de Geologia, 25, São Paulo, 1971. Anais.. São Paulo, SBG v. 1, p. $105-110$.

Couto, C de P 1953. A bacia calcária de haboraí e a tectônica da costa sudeste do Brasil. Rio de Janeiro: Divisão de Geologia e Mineralogia, DNPM. 12p. (Notas Preliminares e Estudos, 75).

Couto, C. de P. 1958. Idade geológica das bacias cenozóicas do Vale do Paraíba e de Itaboraí. Rio de Janeiro: Boletim do Museu Nacional. 17p. (Geologia, 25)

Ferreira, A.L. 1990. A geologia do "rift" da Guanabara (RJ) na sua porção centro ocidental e sua relação com o embasamento pré-cambriano. In Congresso Brasileiro de Geologia, 36, 1990, Natal. Anais... Natal: SBG., v. 6, p. 2851-2872.

Ferreira, F.J.F.; Moraes, R.A.V.; Ferrari, M.P.; Viana, R.B. 1981. Contribuição ao estudo do Alinhamento Estrutural de Guapiara. In: Simpósio Regional de Geologia, 3, Curitiba, 1981. Atas... Curitiba, SBG. v. 1, p. 226-240.

Fiori, A.P. 1994. Evolução geológica da bacia Açungui. Boletim Paranaense de Geociências, n. 42, p. 7-27.

Furtado, V.V.; Bonetti Filho, J.; Conti, L.A. 1996. Paleoriver valley morphology and sea levei changes at southeastern Brazilian continental shelf. Anais da Academia Brasileira de Ciências, v. 68 (supl.), p. 163-169.

Gallagher, K.; Hawkesworth, C.H.; Mantovani, M.S.M. 1994. The denudation history of the onshore continental margin of the SE Brazil inferred from apatite fission track data. Journal of Geophysical Research, 99, n. B9, p. 18,117-18,145.

Hasui, Y. \& Cordani, U.G. 1968. Idades potássio-argônio de rochas eruptivas mesozóicas do oeste mineiro e sul de Goiás. In: Congresso Brasileiro de Geologia, 22, Belo Horizonte, 1968. Anais.., Belo Horizonte, SBG. p. 139-143.

Hasui, Y.; Gimenez, A.F.; Melo, M.S. de. 1978. Sobre as bacias tafrogênicas do sudeste brasileiro. In: Congresso Brasileiro de Geologia, 30, 1978 Anais... Recife: SBG, v. 1, p. 382-392.

Hasui, Y. \& Sadowski, G.R. 1976. Evolução geológica do Pré-Cambriano na região sudeste do Estado de São Paulo. Revista Brasileira de Geociências, v. 6, n. 3, p. 182-200.

Hennies, W.T. \& Hasui, Y. 1977. Contribuição ao reconhecimento da geologia da Ilha de São Sebastão. In: Simpósio Regional de Geologia, São Paulo, 1977. Atas... São Paulo: SBG/NSP. p. 199-209.

Kaul, P.F.T. \& Cordani, U.G. 1994. Aspectos petrográficos, geoquímicos e geocronológicos dos macicos graníticos da Serra do Mar no leste paranaense e vizinhanças. In: Congresso Brasileiro de Geologia, 38, Baln. Camboriú, 1994. Boletim de Resumos Expandidos... Baln. Camboriú: SBG. v. 2, p. 371-373.

Klein, V.C. \& Valença, J.G. 1984. Estruturas almofadadas em derrame ankaramítico na Bacia de São José de Itaboraí, Rio de Janeiro. In: Congresso Brasileiro de Geologia, 33, Rio de Janeiro, 1984. Anais... Rio de Janeiro: SBG. v. 9, p. 135-142.

Lauar, C.R.M. 1988. Paleomagneíismo e correlações com idades radiométricas: alguns exemplos. São Paulo, (semin., IG/USP).

Ledent, D. \& Pasteels, P. 1968. Determinations de l'âge dês roches post-tectoniques du sud-est du Brésil. Annales Societé Geólogique de Belgique, n. 91, p. 305-309.

Lima, M.R. de; Cabral Jr., M.; Stefani, F.L. 1996. Palinologia dos sedimentos da Formação Macacu - Rifte da Guanabara. Terciário do Estado do Rio de Janeiro, Brasil. Anais da Academia Brasileira de Ciências, v. 68, n. 4, p. $531-542$.

Lima, M.R. \& Angulo, R.J. 1989. Descoberta de microflora em um nível linhítico da Formação Alexandre, Terciário do Estado do Paraná, Brasil. In: Congresso Brasileiro de Paleontologia, 11, Curitiba, 1989. Boletim de Resumos das Comunicações... Curitiba: SBG. p. 100.

Maack, R. 1968. Geografia Física do Estado do Paraná. Curitiba: Banco de Desenvolvimento do Estado do Paraná, Universidade Federal do Paraná e Instituto de Geologia e Pesquisas Tecnológicas, 350p.

Macedo, J.M. 1991. Evolução tectônica da Bacia de Santos e áreas continentais adjacentes. In: GABAGLIA, G.P.R.; MILANI, E.J. coords. Origem e evolução de bacias sedimentares. Rio de Janeiro. 1991. PETROBRÁS. p. 361-374.

Martonne, E. de. 1933. Abrupts de faille et captures recents. La Serra do Mar et 1'Espinausse. Association dês Geographes Français, Bulletin, n. 74, p. 138-145. Paris.
Martonne, E de 1943. Problemas morfológicos do Brasil tropical atlântico. Revista Brasileira de Geografia, ano 1, n. 4, p. 523-550. Rio de Janeiro.

Méis, M.R.M. de \& Amador, E.S. 1977. Contribuição ao estudo do Neocenozóico da Baixada da Guanabara: Formação Macacu. Revista Brasileira de Geociências, v. 7, n. 2, p. 150-174

Melo, M.S. de \& Pires Neto, A.G. 1977. Esboço geológico da província costeira entre as serras do Juqueriquerê e Parati, Estado de São Paulo. In: Simpósio Regional de Geologia, 1, 1977, São Paulo. Atas... São Paulo: SBG/SP. p. 303-323.

Melo, M.S. de; Coimbra, A.M.; Moraes, M.C.de; Fernandes, L.A. 1990a. Redefinição da Formação Pariquera-açu, Cenozóico do Estado de São Paulo. In: Congresso Brasileiro de Geologia, 36,1990, Natal. Anais... Natal: SBG., v. 1, p. 324-338.

Melo, M.S. de; Fernandes, L.A.; Coimbra, A.M. 1990b. Evolução tectono-sedimentar cenozóica do baixo vale do rio Ribeira de Iguape, SP. In: Congresso Brasileiro de Geologia, 36, 1990, Natal. Anais.. Natal: SBG., v. 5, p. 2250-2260.

Melo, M.S. de; Fernandes, L.A.; Coimbra, A.M.; Ramos, R.G.M. 1989. O gráben (Terciário?) de Sete Barras, vale do Ribeira de Iguape, SP. Revista Brasileira de Geociências, v. 19, n. 2, p. 260-262.

Melo, M.S. de; Riccomini, C.; Hasui, Y: Almeida, F.F.M. de 1985. Geologia e evolução das bacias tafrogênicas continentais do sudeste do Brasil. Revista Brasileira de Geociências, v. 15, n. 3, p. 193-201.

Mioto, J.A. 1984. Mapa de risco sísmico do sudeste brasileiro. São Paulo: IPT. (IPT, Monografias 10).

Moriak, W.U. \& Barros, A.Z.N. 1990. Novas evidências de tectonismo cenozóico na região sudeste do Brasil: o Gráben de Barra de São João plataforma de Cabo Frio, RJ. Revista Brasileira de Geociências, v. 20, n. 1-4, p. 187-196.

Ojeda, H.A. \& Cesero, P. 1973. Bacias de Santos e Pelotas, geologia e potencialidade petrolifera. Rio de Janeiro: PETROBRAS/DEPEX. (Rei. Int.)

Pereira, M.J. 1992. Considerações sobre a estratigrafia do Cenomaniano-Santoniano em algumas bacias continentais brasileiras e sua implicação na história tectônica e sedimentar da margem continental. Boletim Geociências Petrobrás, v. 6, n. 3/4, p. 171-176.

Pereira, M.J.; Barbosa, C.M.; Agre, J.; Gomes, J.B; Aranha, L. G. F.; Saito, M.; Ramos, M.A.; Carvalho, M.D. de; Stamato, M.; Bagni, O. 1986. Estratigrafia da Bacia de Santos: análise das sequências, sistemas deposicionais e revisão litoestratigráfica. In: Congresso Brasileiro de Geologia, 34, Goiânia, 1986. Atas... Goiânia: SBG. v. 1, P, 65-79.

Pereira, M.J. \& Feijó, F.J. 1994. Bacia de Santos. Boletim Geociências Petrobrás, v. 8, n. 1, p. 219-234.

Pires Neto, A.G.; Ponçano, W.L.; Carneiro, C.D.R.; Stein, D.P. 1979. Carta Geomorfológica dos Morros de Santos e São Vicente, SP. In: Simpósio Regional de Geologia, 2, Rio Claro, 1919.Atas... Rio Claro: SBG/NSP, v. 2, p. 279-290.

Ponçano, W.L. et al. 1981. Notícia Explicativa do Mapa Geomorfológico do Estado de São Paulo. São Paulo: IPT. 94p. (IPT, Monografias 5).

Ribeiro, F.E. \& CORDANI, U.G. 1966. Contemporaneidade das intrusões de rochas sieníticas do Itatiaia, Passa Quatro e Morro Redondo. In: Congresso Brasileiro de Geologia, 20, Vitória, 1971. Publicação. Vitória, Núcleo Rio de Janeiro/SBG, v. 1, p. 62-63.

Riccomini, C. 1989. O Rift continental do sudeste do Brasil. São Paulo: Instituto de Geociências Universidade de São Paulo. (Tese de Doutoramento).

Riccomini, C.; Melo, M.S.de; Carneiro, C.D.R.; Almeida, F.F.M.de; Mioto, J.A.; Hasui, Y. 1983. Sobre a ocorrência de um derrame de ankaramito na Bacia de Volta Redonda (RJ) e sua importância na datação das bacias tafrogênicas continentais do sudeste brasileiro. In: Simpósio Regional de Geologia, 4, São Paulo, 1983. Resumos... São Paulo, SBG/NSP. p. 23-24.

Riccomini, C.; Pellogia, A.U.G.; Saloni, J.C.L.; Kohnke, M.W.; Figueira, R.M. 1989. Neotectonic activity in the Serra do Mar rift system (southeastern Brazil). Journal of South American Earth Sciences, v. 2, n. 2, p. 191-197.

Rich, J.L. 1953. Problems in brazilian geology and geomorphology suggested by reconnaissance in summer of 1951 . Faculdade de Filosofia, Ciências e Letras, USP, São Paulo, Boletim 146, p. 3-79 (Geologia, 9).

Ruellan, F. 1944. A evolução geomorfológica da baía da Guanabara e das regiões vizinhas. Revista Brasileira de Geografia, ano VI, n. 4, p. 445-508.

Sadowski, G.R. 1974. Tectônica da Serra de Cubatão. São Paulo: Instituto de Geociências Universidade de São Paulo. 159p. (Tese de Doutoramento).

Salamuni, E. 1995. Dobramentos e redobramentos superpostos na porção sul da Zona de Cisalhamento Lancinha-Cubatão. Boletim Paranaense de Geociencias, n. 43, p. 135-149.

Santoro, E.; Carneiro, C.D.R.; Hasui, Y. 1979. Análise Geométrica do Fraturamento nos Morros de Santos e São Vicente, SP. In: Simpósio Regional de Geologia, 2, Rio Claro, 1979.Atas... Rio Claro: SBG/NSP. v. 2, p. 1-12. 
Schobbnehaus, C.; Campos, D.A.; Derze, G.R.; Asmus, H.E. coords. 1981 Mapa Geológico do Brasil e da área oceânica adjacente, incluindo depósitos minerais; escala 1:2.500.000. Brasília: DNPM/MME. (4 folhas).

Siga Jr., O.; Basei, M.A.S.; Reis Neto, J.M.; Harara, O.M.; Passarelli, C.R.; Prazeres, H.; Weber, W.; Machiavelli, A. 1997. Ages and tectonic setting of alkaline-peralkaline granitoids of Paraná and Santa Catarina States, southern Brazil. In: South American Symposium on Isotope Geology, 1997, Campos do Jordão, SP. Extended Abstracts... São Paulo: s.c.p., p. 301-303.

Souza, L.A.P.; Tessler, M.G.; Galli, V. 1996.0GrábendeCananéia.Revista Brasileira de Geocièncias, v. 26, n. 3, p. 139-150.

Souza, L.A.P. 1995. A planície costeira Cananéia-Iguape, litoral sul do Estado de São Paulo: um exemplo de utilização de métodos geofísicos no estudo de áreas costeiras. São Paulo: Instituto Oceanográfico, USP. 207p. (Dissertação de mestrado)
Suguio, K. 1996. Papel da Neotectônica na evolução do litoral brasileiro. In Congresso Brasileiro de Geologia, 38, Salvador, 1996. Boletim de Resumos Expandidos... Salvador: SBG. v. 5, p. 473-476.

Vignol-Lelarge, M.L.M.; Soliani Jr., E.; Poupeau, G. 1994. Datação pelos traços de fissão do domínio meridional da Serra do Mar (Arco de Ponta Grossa - Brasil). In: Congresso Brasileiro de Geologia, 38, Baln. Camboriú, 1994. Boletim de Resumos Expandidos... Baln. Camboriú: SBG. v. 2, p. 379-380.

White, I.C. 1908. Relatório Final. Comissão de Estudo das Minas de Carvão de Pedra. Rio de Janeiro: s.c.p., 617 p.

Manuscrito A-949

Recebido em 18 de novembro de 1997 Revisão dos autores em 20 de maio de 1998 Revisão aceita em 27 de maio de 1998 